\title{
Maize Dwarf Mosaic Virus: From Genome to Disease Management
}

\author{
Maathavi Kannan ${ }^{1}$, Ismanizan Ismail ${ }^{1,2}$ and Hamidun Bunawan ${ }^{1, *}$ \\ 1 Institute of Systems Biology, Universiti Kebangsaan Malaysia, 43600 Bangi, Malaysia; \\ maathavikannan95@gmail.com (M.K.); maniz@ukm.edu.my (I.I.) \\ 2 School of Bioscience and Biotechnology, Faculty of Science and Technology, Universiti Kebangsaan Malaysia, \\ 43600 Bangi, Malaysia \\ * Correspondence: hamidun.bunawan@ukm.edu.my; Tel.: +60-3-8921-4554
}

Received: 24 July 2018; Accepted: 28 August 2018; Published: 13 September 2018

check for updates

\begin{abstract}
Maize dwarf mosaic virus (MDMV) is a serious maize pathogen, epidemic worldwide, and one of the most common virus diseases for monocotyledonous plants, causing up to $70 \%$ loss in corn yield globally since 1960. MDMV belongs to the genus Potyvirus (Potyviridae) and was first identified in 1964 in Illinois in corn and Johnsongrass. MDMV is a single stranded positive sense RNA virus and is transmitted in a non-persistent manner by several aphid species. MDMV is amongst the most important virus diseases in maize worldwide. This review will discuss its genome, transmission, symptomatology, diagnosis and management. Particular emphasis will be given to the current state of knowledge on the diagnosis and control of MDMV, due to its importance in reducing the impact of maize dwarf mosaic disease, to produce an enhanced quality and quantity of maize.
\end{abstract}

Keywords: Maize dwarf mosaic virus; genome; transmission; symptomatology; diagnosis; management

\section{Introduction}

Maize (Zea mays L.) is one of the most highly cultivated crops worldwide. It is the third largest crop grown in the developing world and it has been identified as a major staple food in Africa [1]. In south and eastern Africa, maize serves as a primary food for more than 24 million families and also as a subsistence food source for poor populations outside Asia [2]. Approximately 177 million hectares of tropical, semitropical and temperate zones are used to cultivate maize [3] and 875 million metric tons of maize are produced every year [4].

More than 50 viruses have been shown to infect maize [5]. These include Sorghum mosaic virus (SrMV) [6,7], Johnsongrass mosaic virus (JGMV) [8], Maize chlorotic mottle virus (MCMV), and Maize chlorotic dwarf virus (MCDV) [9]. Among all the maize-infecting viruses, Maize dwarf mosaic virus (MDMV) is the most common disease agent in this monocotyledonous crop globally [10], with incidences of maize dwarf mosaic (MDM) disease reported in Africa, United States, Asia and Europe [11].

MDMV strains' nomenclature was in a state of confusion, since MDMV is intimately correlated with the Sugarcane mosaic virus (SCMV) [12]. The organization of inclusions and alterations produced by four isolates representing different virus strains from the subgroup of SCMV in infected cells were studied and differentiated by cellular pathology [13]. The results obtained demonstrated the presence of typical inclusions only in MDMV infected cells, but laminar aggregations were also exist in SCMV infected cells [14]. 
MDMV is classified in Potyviridae, the most numerous group of plant viruses [15]. There are 8 genera under the family; Potyvirus, Tritimovirus, Brambyvirus, Rymovirus, Ipomovirus, Bymovirus, Macluravirus, and Poacevirus [16]. MDMV belongs to the genus Potyvirus. In 1964, flexuous rod-shaped MDMV with a length of $750 \mathrm{~nm}$ and diameter of 12-15 $\mathrm{nm}$ was identified for the first time in Illinois [17]. MDMV is a holoparasite that requires a vector or host to reproduce and survive [18]. The infected plants take up to 15 days to exhibit the symptoms [19]. In this case, both serological and molecular methods have been developed to diagnose the MDM diseased plants more efficiently, eliminating the dependence on symptoms observation for identification purposes. The viral particles were observed to be distributed generally in cytoplasm and infrequently in plasmodesmata [20]. The lowest temperature needed to inactivate MDMV completely is $54-58^{\circ} \mathrm{C}$. At room temperature, survival in vitro for MDMV lasts $1-2$ days while at $0-4{ }^{\circ} \mathrm{C}$, it lasts $3-5$ days [21,22].

In general, the loss in maize yield caused by MDMV can be up to $70 \%[23,24]$, mainly due to a reduction in the rate of photosynthesis and elevation in the rate of respiration [25]. Taking into account the economic significance of the disease, our current review has discussed available information from genome to global management of MDMV, so that greater effort would be put towards further research work in controlling MDM disease for the maintenance of profitable production and the good health of maize crops in future.

\section{Genome}

Like other potyviruses, MDMV is a positive-stranded RNA $[18,26]$. The MDMV genome is 9500 base pairs in length with a covalently bounded viral-genome-linked protein, VPg at its $5^{\prime}$ end as well as a poly (A) tail attached to its $3^{\prime}$ end [10]. A large $338 \mathrm{kDa}$ polyprotein is translated from a single open reading frame (ORF) [27], which is subsequently proteolytically cleaved by three self-coded proteinases to yield 10 final proteins (P1, HC-Pro, P3, 6K1, CI, 6K2, NIa-VPg, NIa-Pro, NIb, and CP) with multiple functions [28,29]. The last cistron that encodes the capsid protein (CP) [30] is greatly conserved among numerous potyvirus species [31]. This protein subunit of MDMV has a molecular weight of $28.5 \times 10^{3}$ according to amino acid analyses [32]. The C-terminal regions of the coat protein primarily plays a role in the process of encapsidation and cell-to-cell transport and the flexible N-terminus is involved in long distance and systemic transport and contains the DAG motif essential for aphid transmission competence [33].

Several complete sequences of MDMV isolates are currently available (Table 1). The viral genome of MDMV-BG is composed of 9515 nucleotides and contains an open reading frame encoding 3042 amino acids, flanked by 30 and 50 untranslated regions (UTRs) of 139 and 250 nucleotides, respectively. Meanwhile, the genome of MDMV-Sp is made up of $9414 \mathrm{nt}$ and contains one ORF encoding 3042 amino acids, flanked by 50 and 30 UTRs of 138 and 234 nucleotides, respectively. The similarities in nucleotide and amino acid sequence between MDMV-BG and MDMV-Sp are 85\% and 93\%, respectively [27]. MDMV-OH1 encoded P1 protease (nt 1400-838), HC-Pro (nt 839-2218), P3 protease (nt 2219-3259), 6K1 (nt 3260-3460), CI (nt 3461-5350), 6K2 (nt 5351-5509), NIa-VPg (nt 5510-6076), NIa-Pro (nt 6077-6802), NIb-replicase (nt 6803-8365), CP (nt 8366-9180). It also encodes the "PIPO" (nt 2678-2922) that overlaps the P3 gene. PIPO is a new ORF recently described to be expressed as a result from the transcriptional slippage specific to the viral RNA polymerase [34], it well conserved and has a strong bioinformatics coding signature throughout the Potyviridae family members [35]. It is translated in the +2 reading frame relative to the potyviral long ORF as the P3N-PIPO fusion protein [36]. Potyviral P3N-PIPO interacts with the PCaP1 host plasma membrane protein to function in cell-to-cell movement [37]. MDMV-OH1 has an identity of about $97 \%$ and 98\% in nucleotide sequences and polyprotein amino acid sequences respectively with MDMV-OH2. Both MDMV-OH isolates are more related to MDMV-It isolate rather to other European isolates based on the phylogenetic tree constructed. 
Table 1. Available complete sequences of maize dwarf mosaic virus (MDMV) isolates.

\begin{tabular}{cccc}
\hline MDMV Isolates & Geographical Origin & Genbank Accession & References \\
\hline MDMV & Golestan & JQ280313 & {$[38]$} \\
MDMV-Bg & Bulgaria & NC003377 & {$[27]$} \\
MDMV-Sp & Spain & AJ416645 & {$[39]$} \\
MDMV-OH1 & Ohia & JQ403608 & {$[40]$} \\
MDMV-OH2 & Ohia & JQ403609 & {$[40]$} \\
MDMV-It & Italy & JX185302 & {$[41]$} \\
\hline
\end{tabular}

The construction of the full-length infectious cDNA clones has been an important technique in the understanding of virus fundamental mechanisms studies [42]. Moreover, generation of infectious clone allows mutagenesis studies, insertion, substitution and deletions, to be conducted at any particular region of the viral genome [43]. Gell [44] initiated the attempt to develop the full-length virulent MDMV clones. Unfortunately, no typical symptoms of MDMV infection were observed in the inoculated plants and no viral particles were detected using the polymerase chain reaction (PCR) approach. The next attempt was made in 2012, Stewart et al. [40] managed to produce the full-length infectious MDMV cDNA clone using MDMV-OH1 isolate. The study managed to overcome the toxicity exhibited by plasmids containing full-length MDMV in Escherichia coli. According to Ali et al. [45], cDNA clones are often unstable due to the toxicity of the viral proteins such as P3 and CI for bacteria.

In earlier literature, there was a considerable confusion in the taxonomy of the potyvirus, due to huge size of the group and wide diversification among the species [6]. MDMV strains have been differentiated serologically $[46,47]$ and by host range $[48,49]$. Serological relationship investigation of 13 American and 4 Australian strains of MDMV and SCMV using virus-specific polyclonal antisera directed against $\mathrm{N}$-terminal regions of their coat proteins led to the establishment of four groups of viruses: (1) MDMV (MDMV-A, MDMV-D, MDMV-E, MDMV-F); (2) SCMV (MDMV-B); (3) JGMV (MDMV-O) and (4) SrMV forming a subgroup of SCMV [50]. This shows that a serological approach has the potential to be utilized as a taxonomic parameter.

In the context of host range, of the two principal strains, MDMV-A was found to be a johnsongrass-infecting strain, while MDMV-B is a non-johnsongrass-infecting strain [51]. MDMV-A was further differentiated from MDMV-B by the means of relative molecular mass (Mr) of RNA. Mr of MDMV-A RNA derived from three methods showed a value of $3.3 \times 10^{6}$ and for MDMV-B, it was reported as $3.0 \times 10^{6}$ [52]. Comparison in RNA nucleotide composition showed that both MDMV-A and MDMV-B strains consist of adenylic and guanylic acids in same quantity. Nevertheless, their high adenylic content in general adds credence to the suggestion that high content of adenylic acid might be a characteristic of potyviruses [53]. Furthermore, MDMV-A has a higher cytidylic acid content but lower uridylic acid content than MDMV-B [32].

\section{Transmission}

Aphids are the most widely spread vectors of plant viruses and have the potential to transmit both persistent and non-persistent viruses. Aphids transmit more than 200 species of plant viruses in a non-persistent way [54]. Among them, insects of the order Homoptera, with their piercing-sucking mouthparts, are highly efficient plant viral vectors. Within this order, the softbodied aphids (Family Aphididae) account for more than $50 \%$ of the vector species that transmit over $60 \%$ of the viruses [55]. Over 20 different aphid species are able to transmit MDMV non-persistently [56]. The broad range includes Rhopalosiphum maidis (Fitch) (Figure 1), Myzus persicae (Sulzer), Rhopalosiphum padi (Linnaeus), Rhopalosiphum poae (Gill.), Brevicoryne brassicae (Linnaeus) and Rhopalosiphum fitchii (Sand.) [57].

MDMV has a short acquisition access period (AAP) of 10-30 s [58]. Aphid transmission of the virus is closely correlated to the retention of the virus in stylets [59]. Berger et al. [60] also discovered that retention of MDMV was much longer when increasing the time of acquisition time. Previously, 
periods of retention around 15-20 min have been recorded [58,61]. However, longer periods of up to $240 \mathrm{~min}$ have also been recorded by for the retention of MDMV-A by M. persicae [62].

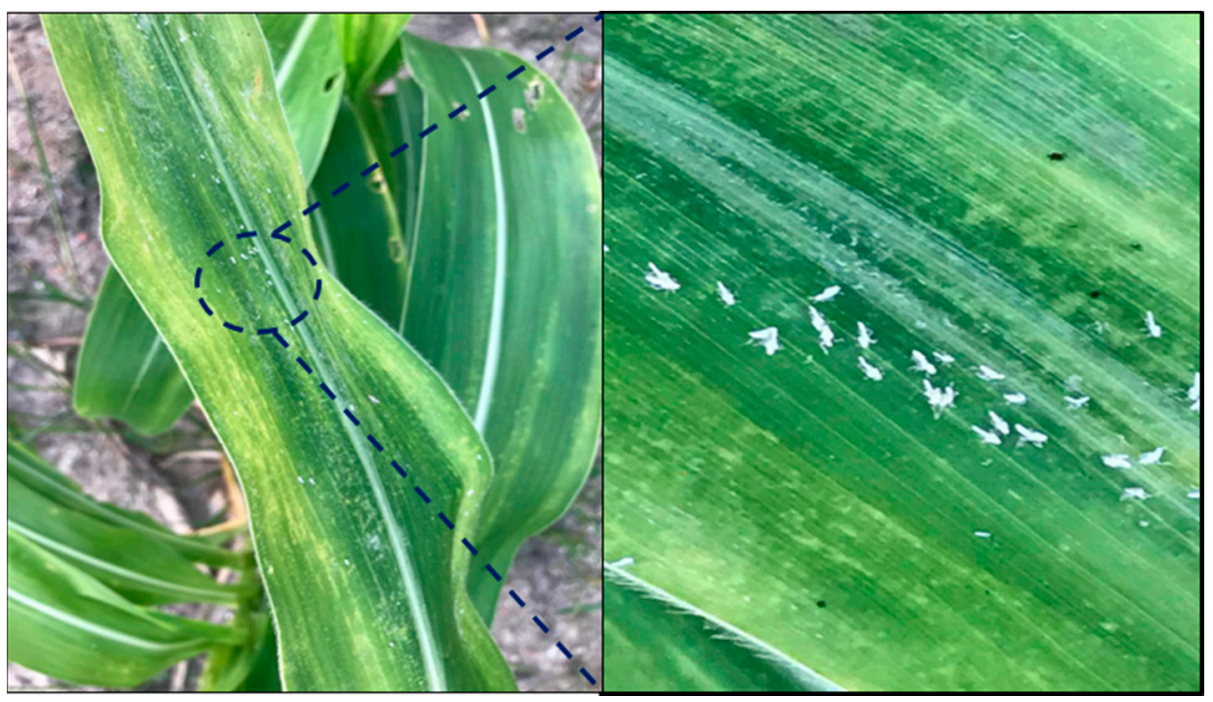

Figure 1. Mosaic symptoms on the lower leaves and yellow streaks along veins in corn plant as it approaches maturity. Also the fitch, Rhopalosiphum maidis, nymphs on the maize leaves.

Appendages of aphids are where the virus particles have been retained either directly or indirectly before being inoculated into plants. There are two viral encoded factors that mediated the attachment of viruses to the appendages of aphids in indirect binding, the $\mathrm{CP}$ as the component of virion and the helper component-proteinase (HC-Pro) [63]. Helper component is a non-structural protein found in diseased plants but not in healthy tissues. The HC-Pro protein forms interactions between the stylet of vector and the virus coat protein, thus performs its function as a "molecular bridge" (Figure 2) [64,65]. Transmission of potyviruses is linked to a triplet 3-amino acid sequence, DAG (Asp-Ala-Gly), near the $\mathrm{N}$-terminal region of the coat protein [66]. The simplest hypothesis to explain the behavioural difference of the $\mathrm{N}$-terminus of the $\mathrm{CP}$ when it acts as a part of the virus particle or as free protein is that in the entire particle, the N-terminus is not available to interact with the aphid's stylet and so the presence of HC-Pro is needed to cause a structural change, unfolding the N-terminus of the coat protein. Since the DAG triplet in the $\mathrm{N}$-terminal region of the coat protein is crucial for aphid transmission [67], substitution of any of the 3 amino acid residues or the residue after the DAG motif will minimise aphid transmission drastically, but not mechanical transmission of the virus. Although the viral factors involved in transmission are quite clear, the receptors in aphids that allow retention as well as inoculation of non-persistent viruses remain unidentified but are believed to be localised at the distal edge of the stylet bundle $[68,69]$.

Transmission occurs at different rates according to the influence of several factors. Firstly, fasted aphids transmit potyviruses more effectively (15\%) compared to non-fasted aphids (5\%) [70]. Fasting allows the interfering substances, plant components, to be egested or swallowed, clearing the alimentary canal, and hence enhances the virions retention in aphid's stylet [71]. Furthermore, transmission of MDMV was positively related to leaf age, as the MDMV concentration was lower in older leaves, resulting in decreased aphid transmission [70]. It was found that a group of aphids improved MDMV transmission compared to single aphid transfer. This is probably due to the relatively short retention period and low transmission rate of MDMV. In addition, the efficiency of aphid transmission of MDMV is generally related to virus concentration in vivo in corn leaves. Therefore, any factors such as nutrition, host species, temperature, age of infection that could affect MDMV concentration in vivo in corn most likely would affect the efficiency of aphid transmission directly or indirectly [70]. It was also reported that the aphid species and virus strains greatly affect 
the efficiency of transmission [72]. Last but not least, both temperature and humidity perform an important function in the epidemiological study of MDMV. These factors greatly affect the efficiency and quantity of aphid vectors. For an example, S. graminum developed high populations under low temperature and low humidity early in the season, resulting in massive dispersal of viruliferous adults during the corn growing season [73].

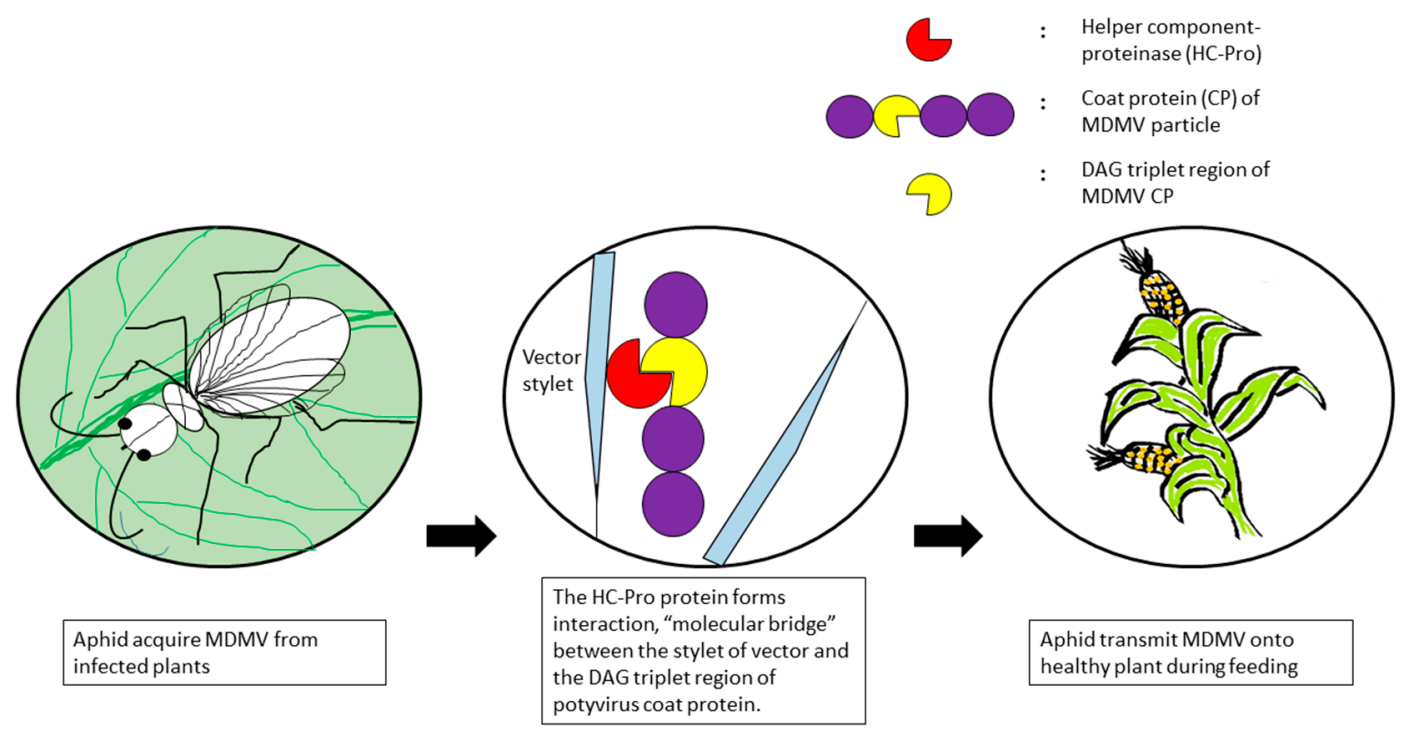

Figure 2. Interaction between MDMV and the vector appendage.

Besides aphid transmission, MDMV can also be seed transmitted [20]. Seed transmission rates of up to $0.5 \%$ have been reported for the incidence of maize dwarf mosaic disease by Boothroyd et al. [74], and its expression appeared to be in two ways: as mosaic symptoms in certain plants and no symptoms in other infected plants. MDMV was present in $0.4 \%$ of field corn and sweet corn seeds [46] as well as in $0.2 \%$ of the tested maize inbred lines [75], both figures are based on symptom expression. Further reported rates for seed transmission in corn are $0.007 \%$ [76], 0.006\% [77], 0.005\% and non-existent [78]. For example, seeds dissected at different maturity stages and analysed for the presence of MDMV viruses through enzyme-linked immunosorbent assay (ELISA) and infectivity tests showed that at 21 days after pollination, MDMV was always discovered in the pericarp, but unfrequently in the endosperm or embryo [78]. The absence of virus infection in the embryo indicated limited or no seed transmission. The proportion of MDMV in seed parts declined from $100 \%$ at 21 days after pollination to rare at maturity in the pericarp. Upon reaching maturity, the pericarp transformed from a very moist nature to a hard, dry membrane. Thus, it is not unexpected since the virus within might have been inactivated. Infecting female gametophytes appeared to be the major MDMV seed transmission mechanism in sweet corn. MDMV was not detected in the male gametophytes, but was present in the unfertilized kernels, silk, glumes and whole anthers [77].

\section{Symptom}

Symptomatology of Maize dwarf mosaic virus has been described in several studies. In general, field plants infected by MDMV exhibit mosaic patterns [79], which normally initiate near the lower part of the youngest leaves and appear uneven and diffuse [18]. Mosaics formed by MDMV-A usually occur between leaf veins and so develop stripes [72]. Mosaics might develop as yellowish streaks that run throughout the edge of the leaf (Figure 1), and may disappear during hot weather and be replaced with common chlorosis in subsequent growth [18]. Chlorotic bands, or an " $\mathrm{A}$ " shape, occur when the chlorotic regions combine forming continuous streaks along the veins. Older plants develop only chlorotic indications on upper leaves and red streaks at times on mature leaves in late infections [73]. 
Other symptoms include mottling spots and irregular necrotic lesions [80]. During progression of earlier symptoms, dark and light green mottles appear on leaves. Formation of mosaics, flecks and rings on leaves is a consequence of an increase in intensity of dark and light green mottles as the disease develops [72]. Infected plant cells have been observed to consist of characteristic inclusion bodies, also known as cytoplasmic inclusions (CI), with closely associated cytoplasmic vesicles $[81,82]$. The CIs are composed of a virus encoded protein subunit with a relative molecular mass of $68 \mathrm{kDa}$ [83].

Overall, infection at juvenile growth stages delays maturity and causes the loss of a large number of kernels at the basal end of the ear, which is usually known as butt blanking [23,24,84]. Occurrence of butt blanking is due to growth retardation of pollen germ tubes on diseased plants' silks [85]. Stunting, reduction in plant weight [86], delay in silking up to four days [87], decrease in ear weight, ear diameter [88], head size and head numbers are also a part of MDMV symptomology. At times, corn plants infected with MDMV might show a delay in flowering as well as a poor grain set and fill [89].

\section{Diagnostic Method}

It is quite challenging to detect virus disease in corn by observing the symptoms alone, since symptoms vary according to plant genotype, infection time, condition of environment, and the potentiality for various infections. In consequence, observable diagnosis is validated using serological and molecular tests (Table 2). Available diagnostics for MDMV include commercialised enzyme-linked immunosorbent assays (ELISA) using antisera and reverse transcription-polymerase chain reaction (RT-PCR) involving virus genome sequence [3].

It is vital for the identification of MDMV to be confirmed using RT-PCR or ELISA. The advantage of RT-PCR is that it is much easier to acquire sequences from the database and thus information about the virus strain and basis of the viral isolates can be gathered [18]. RT-PCR procedure for MDMV strains begins with the grinding of maize infected sample in suitable extraction buffer, such as basic phenol or detergent mixture, followed by addition of ammonium acetate and chloroform-isoamyl alcohol and then centrifugation at low speed to obtain the nucleic acid containing supernatant [90]. Precipitate of the supernatant will be washed using $70 \%$ ethanol and resuspended, from which one microlitre of total RNA will be proceeded to the first cDNA synthesis [30]. This will be carried forward in order to perform RT-PCR using primers specifically designed for amplification of the available MDMV genome sequence. RT-PCR product will be sequenced and compared with known MDMV sequences. This will be carried out by conducting multiple sequence alignment (MSA). A previous study by Giolitti et al. [19] reported that the virus infecting maize fields in Chile is closely related to MDMV isolate from Argentina (MDMV-Arg), since RT-PCR conducted on those infected maize sample from Chile using primers designated for the gene MDMV-Arg capsid protein yielded only one band of the size, as expected. 
Table 2. Methods for Maize dwarf mosaic virus (MDMV) detection.

\begin{tabular}{|c|c|c|c|c|c|}
\hline Method & Platform & $\begin{array}{l}\text { Effect on MDMV } \\
\text { Variation }\end{array}$ & Reliability & Efficiency & References \\
\hline $\begin{array}{l}\text { Indirect Enzyme-Linked } \\
\text { Immunosorbent Assay } \\
\text { (ELISA) }\end{array}$ & $\begin{array}{l}\text { - Rabbit anti-mouse IgM capture } \\
\text { monoclonal antibody } \\
\text { Rabbit anti-mouse IgG second } \\
\text { monoclonal antibody }\end{array}$ & $\begin{array}{l}\text { MDMV-A and } \\
\text { MDMV-B }\end{array}$ & $\begin{array}{l}\text { Allow detection of MDMV-A and } \\
\text { MDMV-B bound IgG among tested leaves } \\
\text { sap infected with several different strains } \\
\text { of MDMV and Sugarcane mosaic virus } \\
\text { (SCMV). }\end{array}$ & $\begin{array}{l}\text { MDMV-A-specific ELISA = antigen } \\
\text { detected in sap at a dilution of 1:60 with } \\
\text { optimal sample pH (7.5-8.5). } \\
\text { MDMV-B-specific ELISA = detect antigen } \\
\text { in sap at dilution end point of 1:2560 }\end{array}$ & [91] \\
\hline $\begin{array}{l}\text { Indirect Enzyme-Linked } \\
\text { Immunosorbent Assay } \\
\text { (ELISA) }\end{array}$ & $\begin{array}{ll}\text { - } & \text { M-C antiserum } \\
\text { M-D antiserum }\end{array}$ & M-C and M-D & $\begin{array}{l}\text { M-C antigen reacts strongly with M-A, } \\
\text { M-D, Sorghum red stripe virus (SRV) } \\
\text { antisera. } \\
\text { M-D antigen reacts strongly with M-D, } \\
\text { M-C antisera. }\end{array}$ & $\begin{array}{l}\text { M-C particles react with M-A and SRV } \\
\text { antisera in the range of } 1: 128 \text { to } 1: 512 \\
\text { dilution end points, with M-D antisera at } \\
\text { dilution end point of } 1: 4 . \\
\text { M-D antigen reacted with homologous } \\
\text { antisera, M-D up to a dilution of 1:512, } \\
\text { with M-C antisera at 1:16 dilution. }\end{array}$ & [88] \\
\hline $\begin{array}{l}\text { Double-Antibody } \\
\text { Sandwich Enzyme-Linked } \\
\text { Immunosorbent Assay } \\
\text { (DAS ELISA) }\end{array}$ & $\begin{array}{l}\text { - Anti-MDMV-A rabbit serum purified } \\
\text { for IgG } \\
\text { - Alkaline phosphatase coupled to purified } \\
\text { IgG as conjugate }\end{array}$ & MDMV-A & $\begin{array}{l}\text { Visual evaluation at absorbance of } 405 \mathrm{~nm} \\
\text { gives reliable information on MDMV-A } \\
\text { presence in leaves extracts tested. }\end{array}$ & $\begin{array}{l}\text { Visible yellow colour formed in wells with } \\
\text { antigen diluted up to } 10^{-4} \text {. Sensitivity is } \\
100 \text { times better than conventional } \\
\text { infectivity test. }\end{array}$ & [92] \\
\hline $\begin{array}{l}\text { Double-Antibody } \\
\text { Sandwich Enzyme-Linked } \\
\text { Immunosorbent Assay } \\
\text { (DAS ELISA) }\end{array}$ & $\begin{array}{l}\text { - IgG purified from polyclonal } \\
\text { anti-MDMV serum } \\
\text { - Alkaline phosphatase coupled to purified } \\
\text { IgG-E as conjugate }\end{array}$ & $\begin{array}{l}\text { MDMV-A, MVMV-J, } \\
\text { MDMV-L, MDMV-SP, } \\
\text { MDMV-YU }\end{array}$ & $\begin{array}{l}\text { Among all reference strains, only MDMV } \\
\text { strains react positively in DAS-ELISA } \\
\text { (recorded OD } 405 \mathrm{~nm} \text { values at least twice } \\
\text { the healthy sap OD } 405 \mathrm{~nm} \text { values) with } \\
\text { anti-MDMV IgG. }\end{array}$ & $\begin{array}{l}\text { IgG antibody dilution to } 1 \mu \mathrm{g} / \mathrm{mL} \text { able to } \\
\text { detect MDMV antigen dilution to } 1 / 100 \text {. }\end{array}$ & [30] \\
\hline $\begin{array}{l}\text { Double-Antibody } \\
\text { Sandwich Enzyme-Linked } \\
\text { Immunosorbent Assay } \\
\text { (DAS ELISA) }\end{array}$ & $\begin{array}{l}\text { - MDMV-Arg (Argentina strain) [93] specific } \\
\text { polyclonal IgG } \\
\text { - Alkaline phosphatase-conjugated IgG as } \\
\text { secondary antibody }\end{array}$ & MDMV & $\begin{array}{l}\text { DAS-ELISA absorbance values of infected } \\
\text { maize leaf samples from field grown plants } \\
\text { and maize leaf sample with MDMV-Arg } \\
\text { isolate were highly significant while the } \\
\text { values from healthy control and buffer } \\
\text { were very low. }\end{array}$ & $\begin{array}{l}\text { MDMV-Arg specific polyclonal IgG } \\
\text { strongly reactive up to 1:2000 dilution with } \\
\text { MDMV antigen from infected field, Chile. }\end{array}$ & [19] \\
\hline $\begin{array}{l}\text { Capture Reverse } \\
\text { Transcription-Polymerase } \\
\text { Chain Reaction (RT-PCR) }\end{array}$ & $\begin{array}{l}\text { Primers designed to MDMV-Arg [93] } \\
\text { capsid protein gene }\end{array}$ & MDMV & $\begin{array}{l}\text { Single band of expected size (1104 bp) } \\
\text { obtained. }\end{array}$ & $\begin{array}{l}\text { Detect MDMV samples from Chile which } \\
\text { closely related to MDMV-Arg (Argentina } \\
\text { strain) efficiently. }\end{array}$ & [19] \\
\hline $\begin{array}{l}\text { Reverse } \\
\text { Transcription-Polymerase } \\
\text { Chain Reaction (RT-PCR) }\end{array}$ & $\begin{array}{ll}\text { - } & \text { Fwd primer = oligo1n: ATGGTHTGGTG } \\
& \text { YATHGARAAYGG } \\
\text { - } & \text { Rvs primer = oligo2n: TGCTGCKGCY } \\
& \text { TTCATYTG } \\
\text { - } & \text { *single lettercode: } \mathrm{H}=\mathrm{A} / \mathrm{C} / \mathrm{T}, \mathrm{Y}=\mathrm{C} / \mathrm{T} \\
\text { - } & \mathrm{R}=\mathrm{A} / \mathrm{G}, \mathrm{K}=\mathrm{G} / \mathrm{T}\end{array}$ & $\begin{array}{c}\text { MDMV-SP, } \\
\text { MDMV-Bu, MDMVJIL }\end{array}$ & $\begin{array}{l}\text { Single product of expected size ( } 327 \mathrm{nts}) \\
\text { obtained for all tested MDMV isolates. }\end{array}$ & $\begin{array}{l}\text { Efficient for dealing with } \\
\text { well-characterized strains, field collected } \\
\text { isolates. }\end{array}$ & [30] \\
\hline
\end{tabular}


Table 2. Cont.

\begin{tabular}{|c|c|c|c|c|c|}
\hline Method & Platform & $\begin{array}{l}\text { Effect on MDMV } \\
\text { Variation }\end{array}$ & Reliability & Efficiency & References \\
\hline $\begin{array}{l}\text { Reverse } \\
\text { Transcription-Polymerase } \\
\text { Chain Reaction (RT-PCR) }\end{array}$ & 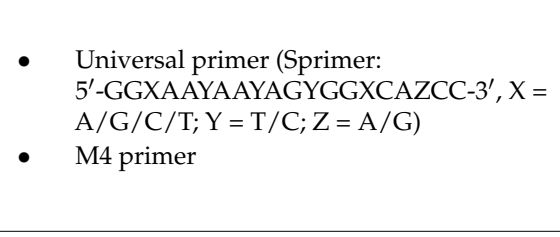 & MDMV & $\begin{array}{l}\text { cDNA fragments of expected size were } \\
\text { amplified from the } 3^{\prime} \text { terminus of RNA } \\
\text { genomes of } 21 \text { different viruses under } \\
\text { family potyviridae including MDMV. }\end{array}$ & $\begin{array}{l}\text { Universal primer designed based on an } \\
\text { alignment of the amino acid sequences } \\
\text { around the conserved GNNSGQP motif in } \\
\text { nuclear inclusion body b (NIb) gene of } \\
\text { family potyviridae members. Hence, it is } \\
\text { proved useful for detection of } \\
\text { potyviridae members. }\end{array}$ & [94] \\
\hline $\begin{array}{l}\text { Reverse } \\
\text { Transcription-Polymerase } \\
\text { Chain Reaction (RT-PCR) }\end{array}$ & $\begin{array}{ll}\text { - } & \text { MDMV F1: } \\
& \text { 5'-CAACCAGGGCYGAATTTGATAG-3' }^{\prime} \\
\text { - } & \text { MDMV R1: 5'-GTGCAAGGC } \\
& \text { TRAAGTCGG TTA-3' }\end{array}$ & MDMV & $\begin{array}{l}\text { Supposed to yield a PCR product of } \\
\text { expected size ( } 336 \mathrm{bp})\end{array}$ & $\begin{array}{l}\text { MDMV can be distinguishable from } \\
\text { Sugarcane mosaic virus, SCMV and } \\
\text { Johnsongrass mosaic virus, JGMV } \\
\text { through RT-PCR }\end{array}$ & [57] \\
\hline $\begin{array}{l}\text { Combined Reverse } \\
\text { Transcription Polymerase } \\
\text { Chain Reaction (RT-PCR) } \\
\text { with } \\
\text { Electrochemiluminescence } \\
\text { method }\end{array}$ & $\begin{array}{l}\text { - } \quad \text { Specific nucleic acid sequences }(20 \mathrm{bp}) \\
\text { were added to } 5^{\prime} \text { terminal of all primers } \\
\text { - } \quad \text { Biotin was introduced into reverse primer }\end{array}$ & MDMV & $\begin{array}{l}\text { PCR yielded a product with a single band } \\
\text { of expected size ( } 643 \mathrm{bp} \text { ) for all } 4 \text { tested } \\
\text { viruses including MDMV. }\end{array}$ & $\begin{array}{l}\text { This method has higher sensitivity and } \\
\text { lower cost than others. It can effectively } \\
\text { detect the MDMV with simplicity } \\
\text { and stability. }\end{array}$ & [95] \\
\hline $\begin{array}{l}\text { Competitive } \\
\text { Radioimmunoassay (RIA) }\end{array}$ & - Rabbit anti-mouse monoclonal IgG & $\begin{array}{l}\text { MDMV-A (referred } \\
\text { here as MDMV-AP) } \\
\text { and MDMV-B }\end{array}$ & $\begin{array}{l}\text { Feasible alternative to the use of polyclonal } \\
\text { antisera in detecting homologous viruses } \\
\text { (MDMV, Soybean mosaic, SMV, Lettuce } \\
\text { mosaic virus, LMV). }\end{array}$ & $\begin{array}{l}\text { Antigen (purified virus) detected at } \\
\text { dilution of } 10-50 \mathrm{ng} / \mathrm{mL} \text {. }\end{array}$ & [96] \\
\hline Dot Blot Immunoassay & - MDMV-Arg [93] polyclonal antiserum & MDMV & $\begin{array}{l}\text { MDMV symptomatic field grown plants } \\
\text { had strong reaction with the polyclonal } \\
\text { antiserum against MDMV-Arg isolate } \\
\text { while healthy plants were negative. }\end{array}$ & $\begin{array}{l}\text { MDMV samples reacted with MDMV-Arg } \\
\text { polyclonal antiserum of dilution up } \\
\text { to 1:5000 }\end{array}$ & [19] \\
\hline $\begin{array}{l}\text { Sodium dodecyl sulfate } \\
\text { (SDS) } \\
\text { immunodiffusion test }\end{array}$ & $\begin{array}{ll}\text { - } & \text { M-D antiserum } \\
& \text { M-D antiserum }\end{array}$ & $\begin{array}{l}\text { MDMV-C and } \\
\text { MDMV-D }\end{array}$ & $\begin{array}{l}\text { M-C antiserum reacted with both M-C and } \\
\text { M-D antigens forming a spur, which } \\
\text { indicate partial serological relatedness. } \\
\text { M-D antiserum reacted with its } \\
\text { homologous viral antigen, M-D. }\end{array}$ & $\begin{array}{l}\text { No precipitin lines were obtained when } \\
\text { antisera reacted against healthy crude sap }\end{array}$ & [88] \\
\hline $\begin{array}{l}\text { DNA Microarray } \\
\text { (Maizepath)-based } \\
\text { detection }\end{array}$ & $\begin{array}{l}\text { Microarray with } 60 \text {-mer oligonucleotide probes } \\
\text { complementary to genomes of } 5 \text { maize } \\
\text { pathogens including MDMV }\end{array}$ & MDMV & $\begin{array}{l}\text { Obtained results indicate that the } \\
\text { fluorescence signals from MDMV, } \\
\text { other pathogens and control probes } \\
\text { are well distinguished in all } \\
\text { performed experiments. }\end{array}$ & $\begin{array}{l}\text { Gives more than } 180 \mathrm{~K} \text { probes in total, } \\
\text { thereby classified as high-density } \\
\text { microarray that able to investigate } \\
\text { thousands of genomic loci in a } \\
\text { high-resolution manner. }\end{array}$ & [97] \\
\hline
\end{tabular}


For the serology part, the principle involved is simple. When an antigen is injected parenterally into the body of a rabbit followed by booster injections, it will trigger the release of particular antibodies. Rabbit will be then bled to obtain the blood serum containing immunoglobulins [88]. The antibodies respond to the antigen that activated their formation specifically in some observable ways. Plant viruses could be used as antigens, and in any plant suspected to have infection the presence of that particular antigen can be determined by using homologous antisera [98]. The ELISA method of serology is a hypersensitive technique for diagnosis of lower antigen concentrations in both crude and purified extract of viruses [99]. Its specificity is also useful for the differentiation of very closely related viral isolates [100]. ELISA tests are extremely cost effective as well as being relatively to use on an easy routine basis.

Although many variations have been developed, most investigators favour the ELISA type called double-antibody sandwich (DAS). A capture antibody is employed to coat a solid phase and is used to immobilize the virus in this assay. A second antibody, conjugated with an enzyme generally alkaline phosphatase is used to detect the immobilized virus by virtue of reaction with a substrate appropriate to the enzyme. The polyclonal antisera utilized in this assay is also often able to respond to antigens from uninfected plant extracts, since the avidity and affinity of the antibody molecule for the virus has been altered, which induced modification in their strain specificity [96]. This is due to the conformational changes in the polyclonal antibody molecule caused by conjugation of the enzyme to the second antibody [101,102]. This problem can often be circumvented by using capture and second antibody prepared in different animal species and detecting the second antibody with an enzyme-conjugated anti-species specific antibody [103]. However, specific antisera from different animal species are often unavailable. The unique characteristics of monoclonal antibodies offer the potential to develop a DAS-ELISA that avoids modifications of second antibody reactivity by molecular conjugation and does not require use of antisera raised in different animal species [92]. Almost all the monoclonal antibodies are specific to the homologous antigen. Utilization of monoclonal antisera for the detection of plant virus in diagnosis and epidemiology is a possible replacement for the use of polyclonal antibodies [96].

For this DAS-ELISA assay, results will be interpreted from the absorbance readings at $405 \mathrm{~nm}$ apart from examining the wells visually or with the aid of a plate reader for any colour change. Development of yellow colour in wells shows positive reactions, whilst negative reactions are demonstrated by no critical development of colour in the wells. Test values are considered to be valid if, and only if, wells of positive control result in a positive reaction while the healthy control and buffer containing wells stay clear. Samples of extract that give absorbance readings greater than two times the average of healthy controls could be read as a positive result [18]. Generally, for the positive results, similar values should be read in comparison of A $405 \mathrm{~nm}$ values of the infected leaves sap to that with purified MDMV.

ELISA was carried out on hundreds of MDMV infected and non-infected corn plant saps, with a 100\% correct result of the positive and negative controls. The sensitivity of ELISA test is 100 times higher compared to the regular tests of infectivity. Hence, application of ELISA for the diagnosis of plant viruses is much encouraged. This is also because the visual evaluation of the assay on the presence of viruses in plant tissue extracts is found to be reliable [92].

\section{Control}

\subsection{Use of Insecticide and Johnsongrass Eradication}

Once the presence of MDMV in plant has been detected, it is important to implement control strategies to reduce further yield loss. Arthropods play a role as a transmitting agent for all economically vital virus-induced diseases, including MDM disease in corn. Hence, occurrence of the disease requires three elements to be present simultaneously in a relevant environment: the virus, the transmitting vector and a vulnerable host [3]. One of the common approaches to control the spread of virus diseases in corn is by interrupting vector-maize interaction by reducing vector 
numbers on susceptible maize. This is possible by applying chemical insecticides or aphicides [104]. However, this method only restricts internal spread of the virus within a site and unfortunately affect the soil fertility [105]. Furthermore, previously Toler [106] demonstrated that MDM disease is relatively unaffected by the use of insecticides. Another common measure to control maize dwarf mosaic is breaking pathogen-vector and pathogen-maize interrelations by eliminating virus sources [3]. Johnsongrass, Sorghum halepense, is the main host of MDMV [107,108]. Yossen et al. [109] identified an MDMV isolate from johnsongrass and the plant can act as an overwintering host providing a shield for the virus [19]. Similarly, infection of MDMV in Spain is reported to be correlated with the abundance of johnsongrass [110]. Therefore, eradication of johnsongrass could effectively limit virus spread [111]. However, it is extremely difficult to do this in fields continuously cropped with maize. Thus, it is advisable to carry out crop rotation with a non-gramineous crop like soy bean, Glycine max, in fields with a perennial johnsongrass problem or a history of maize virus diseases. This has special merit with the advent of new "over-the-top" graminicides that can be used throughout the season in soybean fields to eradicate johnsongrass, with no residue carryover the following year. In addition, troublesome fields could be left fallow for half a season and an intensive effort at johnsongrass eradication could be attempted [73]. Apart from johnsongrass, the mature maize crop has the potential to act as a reservoir of virus for a newly cultivated crop, again serving as a transmitting agent source for viruses [112,113]. In this case, postponing the date of planting maize to prevent the abundancy of vector populations could allow some control over the disease.

\subsection{S-Methylmethionine Pre-Treatment}

Plants are specified with sulphur autotrophy, a series of actions whereby sulphur is absorbed in the oxidised forms from the land, then undergo reduction before being added to cysteine and methionine. The final compound could be converted into S-Adenosylmethionine (SAM), a substrate that takes part as a methyl donor in the synthesis of S-Methylmethionine (SMM) derived from methionine [114,115]. SMM $\left[\left(\mathrm{CH}_{3}\right)_{2}-\mathrm{S}-\left(\mathrm{CH}_{2}\right)_{2}-\mathrm{CH}\left(\mathrm{NH}_{2}\right)-\mathrm{COOH}\right]$ naturally exists in the kingdom plantae as a non-coded and sulphur consisting amino acid [1]. SMM could be converted back into methionine through in a cyclic pathway, called the SMM cycle [116] (Figure 3).

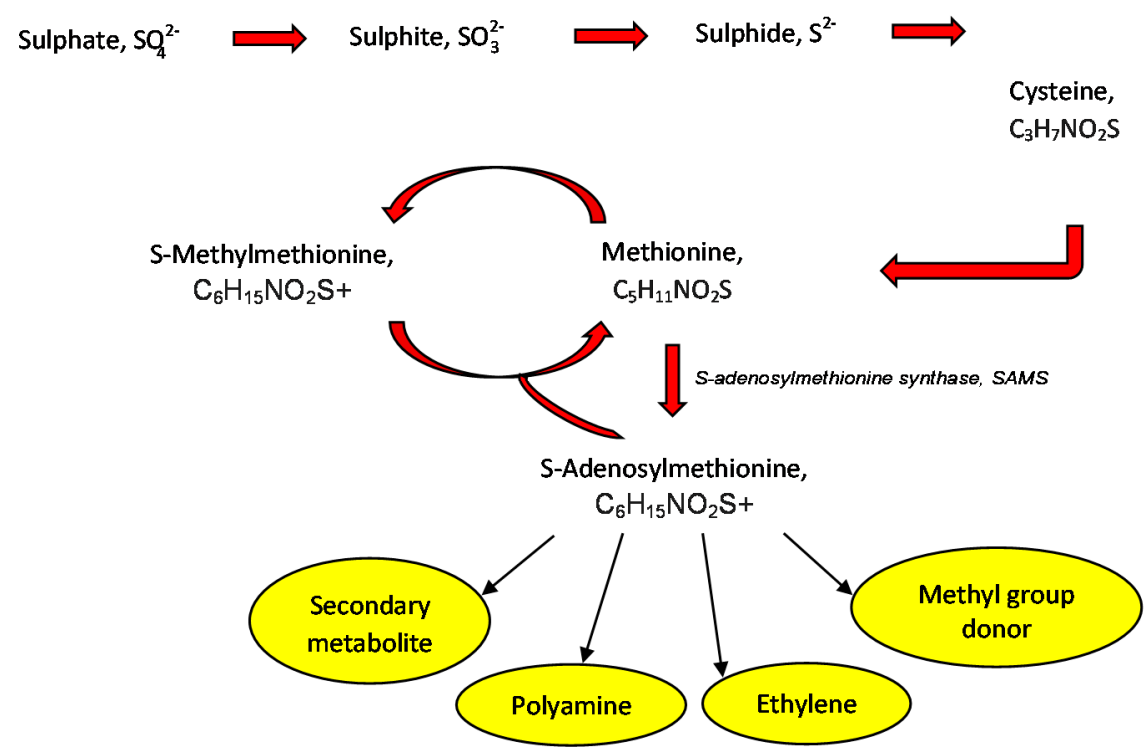

Figure 3. Outline of regulatory and protective compounds anabolism stimulated by S-Methylmethonine.

SMM confers resistance in plants, being a direct precursor of osmoprotectant sulfopropionates, and it also stimulates the anabolism of other regulatory and protective compounds such as polyamine and ethylene $[117,118]$. When stress factors are present, the up-regulation of the phenylpropanoid 
biosynthetic pathway is detected, and that contributes to the production of certain fenoloids, flavonoids and anthocyanins, which are compounds characterised by antioxidant quality and show higher absorbance in the UV spectrum [119]. The potential of SMM has been proven not only against abiotic, but also against biotic stresses, since SMM-treated plants demonstrated higher resistance against Maize dwarf mosaic virus infection. The expression changes of 14-3-3-like protein gene G-box factor 14-6, GF14-6 and S-adenosylmethionine synthase (SAMS) were studied in Ludsmerszki et al. [1] during MDMV infection. The product of GF14-6 recognises and degrades the viral coat protein, contributes to RNA silencing. In the SMM pre-treated and afterwards infected plants, a decline in the GF14-6 expression indicates the improved plant defence due to SMM pre-treatment. Additionally, the more prolonged and long-lasting increment is measured in SAMS expression resulting from SMM pre-treatment followed by the infection indicates the importance of the gene product in upregulating SAM formation for methylation processes, thus raising the SMM circular pathway, and further contributing to defence compounds production [1] (Figure 4). The production of defence compounds due to SMM pre-treatment is further supported in the study by [119]; the study showed an incremental increase in the intensity of emitted fluorescence at 440 and $520 \mathrm{~nm}$ after plants were treated by SMM, which indicates that the amount of phenoloids increased in these plants. Kocsis et al. [120] demonstrated that during stress conditions SMM prevents chlorophyll loss. The value of the F690/F740 ratio is inversely proportional with a decrease in the amount of chlorophyll localised in the leaves, indicating the increase in chlorophyll content when the plants were treated by SMM. Similar results were achieved with chlorophyll-a fluorescence induction measurements. The Fv/Fm value, that indicates the physiological status of the plant, more specifically the maximal quantum efficiency of PSII decreased in the case of infected plants, was analysed but no significant change was detected when the infected plants also got SMM treatment prior to infection [119].

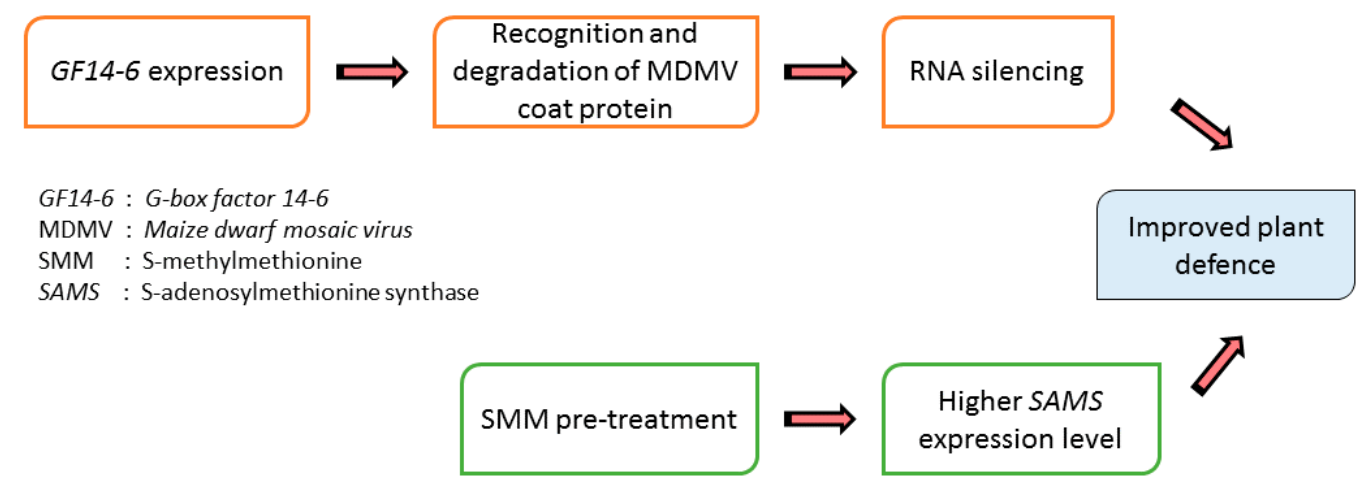

Figure 4. Effects of S-methylmethionine application on GF14-6 and S-adenosylmethionine synthase (SAMS) expression level in MDMV infected maize plants.

Since MDMV disrupts the thylakoid [121] and any damage in thylakoid membranes causes the development of highly reactive oxygen species (ROS), this is an area of research focus. Compared to other species of plants, maize vascular bundle sheath cells are unusually sensitive to oxidative stress [122,123]. This is solved by the existence of antioxidant enzymes, primarily ascorbate peroxidase (APX) and guaiacol peroxidase (GPX) in plant cells, which protect the cell through direct scavenging of those reactive molecules [124]. When the combined molecule of SMM and salicyclic acid (SA), known as S-Methylmethionine salicylate (MMS), was applied before infection, lower levels of enzyme activity were recorded, indicating a decreased resistance level, which can be explained by the reduction in the quantity of virus particles due to MMS pre-treatment [125] (Figure 5).

During MDMV infection, the viral particles accumulate in the cytoplasm of the leaf mesophyll cells and may use chloroplasts for their replication [126,127]. The associations between virus coat protein with PSII reaction centres in thylakoid membranes lead to formation of non-fluorescent trap for excitational energy which subsequently will cause an increase in non-photochemical quenching [128]. 
Accordingly, Ludmerszki et al. [125] reported greater $\Delta \mathrm{pH}$ dependent process high energy state, $\mathrm{qE}$ values for MDMV-infected plants which indicated the appearance of additional quenches of fluorescence in those plants. However, when infected plants were pre-treated with MMS, low qE values were measured, indicating that virus coat protein-thylakoid membrane associations were not formed. This is supported by the ELISA results, showing smaller concentration of MDMV coat protein and viral RNA in the MMS + MDMV plants, giving a clarification for the lower $\mathrm{qE}$ values. In general, the protecting effect of SMM treatment for maize plants prior to stress of MDMV infection is being demonstrated in clear entirely.

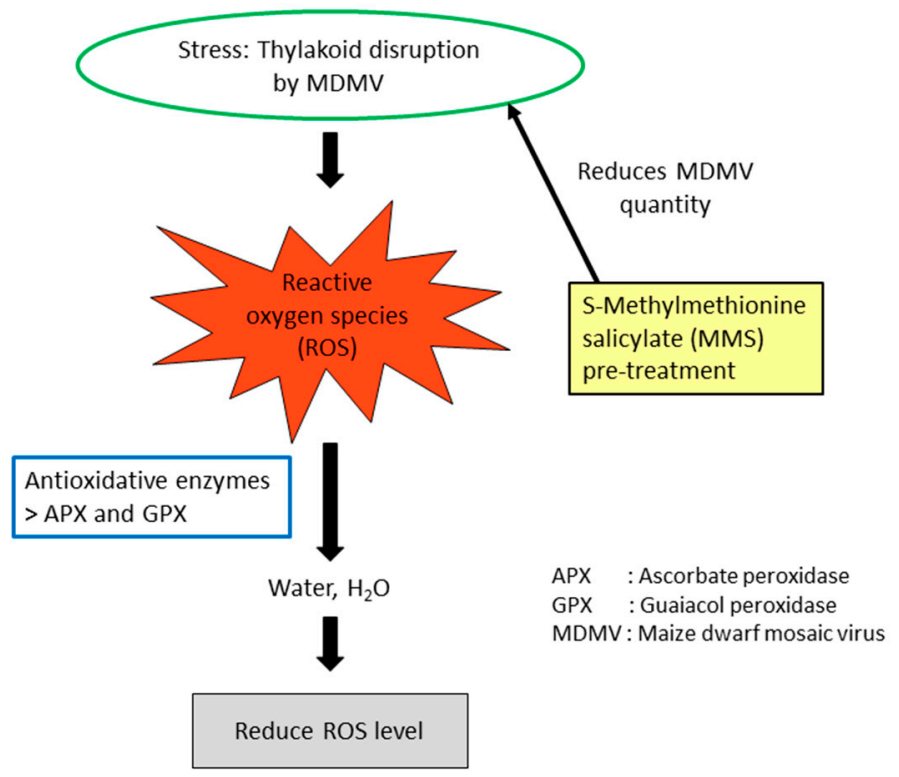

Figure 5. Role of S-Methylmethionine salicylate in the prevention of reactive oxygen species (ROS) development in corn plants.

\subsection{Conventional Resistance Breeding}

The most effective way to protect corn crops against MDMV is through the breeding of maize lines for resistance $[129,130]$. Having a limited knowledge of resistant genes and the pathogens, corn breeders and co-operating pathologists with entomologists suggested that the initial step for this method is the identification of resistance sources through screening of the collected germplasm [3]. The resistance screening methods are comprised of natural infection under field conditions, vector inoculation, mechanical inoculation and growing under greenhouse conditions.

Initially, susceptible inbred lines are crossed with resistant ones, and the F1 generation is produced. Some F1 generations are selfed to result in F2 generations, others are back-crossed with susceptible parents to produce $\mathrm{BC} 1$ generations [131]. Backcrosses have usually been utilized to transfer virus resistance from resistant, but agronomically undesirable, lines to well-adapted elite lines. The recurrent parent is commonly selected due to its ability to combine well, produce high yield and adapt to wider changes [132]. Selection in F2 and BC1 generations seems to be a favourable method to breed new virus-resistant inbred lines. Such selection for resistance under higher temperatures in the greenhouse normally results in the lines with higher resistance level. Accordingly, three dent inbred lines (D21, D32, FAP136OA) with complete resistance, and four dent inbreds (D06, D09, R2306, FAP1396A) with partial resistance against MDMV under both field and greenhouse conditions were determined. Apart from these, the inbred line Pa405 has been found to be the best known source of resistance to MDMV to date $[133,134]$.

Successful screening is continued with identification of markers linked to genes or QTLs exerting resistance, which can be done using reciprocal translocations [135,136], morphological markers [137] 
and restriction fragment length polymorphism (RFLP) analysis $[138,139]$. RFLP analysis of individual back cross plants of the genotypes $(\mathrm{Pa} 405 \times \mathrm{yM} 14$ and $(\mathrm{Pa} 405 \times \mathrm{K} 55) \times \mathrm{K} 55$, inoculated with MDMV, mapped this resistance gene to a region close to the centromere of chromosome 6 . This gene is linked tightly to and located between RFLP marker loci, UMC85 and BNL6.29, and designated as gene Mdm1, gene 1 [140]. $M d m 1$ is crucial for any resistance reaction because all plants with missing $M d m 1$ gene rapidly developed symptoms of generalised mosaics. The resistance dominance of $M d m 1$ was further confirmed in 42 of the 43 inbred lines analysed in the study by [141].

The inheritance of resistance to maize dwarf mosaic disease is also controlled by modifiers or minor genes [142]. For an example, when F1 hybrids, F2 progeny and a recombinant inbred line (RIL) population obtained from a crossing of Oh1V1 to the virus susceptible line Oh28 were examined for their responses to six viruses including MDMV, a dominant QTL responsible for $79 \%$ of total variance and several minor QTLs each contributing to $1 \%$ of the variance mapped to chromosome 3 , and 10 were identified [143]. Moreover, the data representing the percentage of infected plants denoting critical differences both within $\mathrm{F} 1$ generations (from 18 to $34 \%$ ) and within $\mathrm{BC} 1$ generations (from 26 to 53\%) showed that resistance to MDMV is controlled by major genes, yet the minor genes also involved in modification of the resistance [131]. These hybrids and inbred lines with genes for resistance to MDM do not show asymptomatic reactions after infections constantly $[133,144]$. Scott and Rosenkranz [145] mentioned that symptomatic responses maybe resulted from micro environmental influences, expression of resistance at late growth stages, concentrations of inoculum above a specific threshold. Both symptomatic tissue with high virus concentration and asymptomatic tissue with no virus detected formed distinct sectors in resistant hybrids [146]. Similarly, ELISA confirmed existence of both inoculated leaves with a positive response for virus and freshly developed leaves with no virion assembly in the same resistant inbred [147].

This indicates that MDMV can undergo replication and spread from cell to cell in leaves of infected plants, but that a barrier to systemic viral propagation is present in resistant plants. Thus, in resistant plants, the virus is restrained in its movement through the leaf vascular system [147]. The transfer of the resistance from resistant hybrids such as Pioneer Brand (PB) 3187 [148] into selected breeding lines will lead to similar resistance mechanisms and result in successful control over maize dwarf mosaic disease.

\subsection{Genetically Engineered Resistance}

Pathogen-derived resistance, which can be achieved through expression of resistant genes (Table 3), viral proteins or RNAs in transgenic plants through genetic engineering, is another strategy to curb maize dwarf mosaic disease in maize crops $[149,150]$. For this way of controlling, it is important to acquire knowledge on the concept of resistance expression genetically. As explained earlier, the virus resistance in maize was due to an obstruction to systemic movement of virus in resistant plants [151] where the movement could be prevented by inhibition of the loading of virions, ribonucleoprotein [152], or RNA into phloem or unloading from phloem in either leaves or roots [148]. However, for a better understanding on the mechanism for genetic resistance, global transcriptional response of resistant (Pa405) and susceptible (Oh28) inbred lines was analysed in germinating maize embryos at 4 days post inoculation (dpi). There were no groupings of differentially expressed transcripts found in the previously recognised QTLs crucial for MDMW resistance, on chromosome 6, 3 and 10 [153]. Almost $15 \%$ of transcripts were differently expressed between the resistant and susceptible lines. Of transcripts with more than 10 -fold greater expression in one line, more than $70 \%$ were upregulated in the resistant line. Hsp20/alpha crystalline-like gene and cytochrome P450 are among the differentially regulated transcripts that were explained to be involved in virus resistance. The obtained responsive transcripts required to be further studied on in order to figure out their contribution for resistance [154]. 
Table 3. Summary on genes conferring resistance against maize dwarf mosaic virus (MDMV).

\begin{tabular}{|c|c|c|c|c|c|}
\hline Chromosome & Locus & Resistance Source & Screening Method & Level of Resistance & References \\
\hline 6 (short arm) & $M d m 1$ & $\begin{array}{l}\text { Pa405 } \\
\text { Oh1V1 }\end{array}$ & $\begin{array}{l}\text { Mechanical inoculation/Greenhouse } \\
\text { Mechanical inoculation/Field }\end{array}$ & $\begin{array}{l}\text { High resistance } \\
\text { (Dominant gene) }\end{array}$ & {$[140,143]$} \\
\hline 6 & $M d m 1$ co-localizes with Wsm 1 & $\begin{array}{c}\text { Wsm } 1 \text { NIL } \\
\text { (near isogenic lines) } \\
\text { Oh28 } 28^{\mathrm{SS} / \mathrm{RR} / \mathrm{SS}} \\
\text { Left: } W s m 2 \text { alleles } \\
\text { Middle: } M d m 1 / W s m 1 \\
\text { alleles } \\
\text { Right: } W s m 3 \\
\text { (Two } M d m 1 / W s m 1 \text { allele) }\end{array}$ & Mechanical inoculation/Greenhouse/Field condition & High resistance & {$[80]$} \\
\hline 6 & Mdm 1 co-localizes with Wsm 1 & $\begin{array}{c}\text { Wsm } 1 \times \text { Oh2 } 28 \text { F1 } \\
\text { Oh22 } 28 \text { SS/RS/sS } \\
\text { Left: } W s m 2 \text { alleles } \\
\text { Middle: } M d m 1 / W s m 1 \\
\text { alleles } \\
\text { Right: } W s m 3 \\
\text { (One } M d m 1 / W s m 1 \text { allele) }\end{array}$ & Mechanical inoculation/Greenhouse/Field condition & Intermediate resistance & [80] \\
\hline $3 \& 6$ & Wsm 2 combine with $M d m 1 /$ Wsm 1 & $\begin{array}{c}\text { Wsm } 1 \text { Wsm } 2 \text { NIL } \\
\text { Oh28 } 28^{\mathrm{RR} / \mathrm{RR} / \mathrm{SS}} \\
\text { Left: } W s m 2 \text { alleles } \\
\text { Middle: } M d m 1 / W s m 1 \\
\text { alleles } \\
\text { Right: } W s m 3\end{array}$ & Mechanical inoculation/Greenhouse/Field condition & Lowers symptom incidence & {$[80,142]$} \\
\hline $3 \& 6$ & Wsm 2 combine with $M d m 1 /$ Wsm 1 & $\begin{array}{c}\text { Wsm } 1 \text { Wsm } 2 \times \text { Oh2 } 28 \mathrm{~F} 1 \\
\text { Oh } 28^{\mathrm{RS}} / \mathrm{RS} / \mathrm{SS} \\
\text { Left: } W s m 2 \text { alleles } \\
\text { Middle: } M d m 1 / W s m 1 \\
\text { alleles } \\
\text { Right: } W s m 3\end{array}$ & Mechanical inoculation/Greenhouse/Field condition & Lowers incidence and severity of disease & {$[80,142]$} \\
\hline $6 \& 10$ & Wsm 3 combine with $M d m 1 /$ Wsm 1 & $\begin{array}{c}\text { Wsm } 1 \text { Wsm } 3 \times \text { Oh2 } 28 \text { F1 } \\
\text { Oh } 28^{S S / R S / R S} \\
\text { Left: } W s m 2 \text { alleles } \\
\text { Middle: } M d m 1 / W s m 1 \\
\text { alleles } \\
\text { Right: } W s m 3 \\
\end{array}$ & Mechanical inoculation/Greenhouse/Field condition & Lowers disease incidence and severity & {$[80,141]$} \\
\hline $3 \& 6$ & Scmv2 combined with $S c m v 1$ & $\begin{array}{c}\text { F7 RR/RR } \\
\text { Left: } S c m v 2 \text { alleles } \\
\text { Right: } S c m v 1 \text { alleles } \\
\text { R: Susceptible parent } \\
\text { F7 } \\
\text { R: Resistant parent } \\
\text { FAP1360A }\end{array}$ & Mechanical inoculation by rubbing infected leaves & Complete resistance & [155] \\
\hline
\end{tabular}


Another effort of cloning $M d m 1$ allele by chromosome walking was taken to explain the biological basis of $M d m 1$ mediated resistance in resistant maize [156,157]. Although co-segregation of $M d m 1$ with the nucleolus organizer region (nor) in maize caused a difficult obstacle to clone $M d m 1$, yet this initiative still led to the achievement of a high-resolution genetic map in the region of $M d m 1$ that has raised tools for physical mapping of $M d m 1$, which is very useful for subsequent genetic engineering procedures [158].

H9-21 is one of the incorporated resistant germplasms against MDMV previously. However, it does not achieve the rate of maize production required due to its inefficient agronomic characteristics [159]. The attempts to genetically improve resistance against MDMV in maize crops were then continued with the development of engineered lines in order to generate cross protection. Cross protection can be triggered by introducing an antisense sequence homologous to MDMV genes of coat protein $(\mathrm{CP})$, replicase and movement proteins that play a role in viral replication, spreading, and particle coating in the single-standard RNA viral genome [160,161]. Among these genes, maize plants transformed with MDMV protease gene (P1), a replication associated protein gene, proved to be resistant to MDMV under controlled conditions [162]. This was possible by the means of RNA interference (RNAi), mediated by self-complementary hairpin RNA (hpRNA), transcribed from a transgenic inverted-repeat sequence. RNAi has been proved to be more useful in conferring virus resistance through gene silencing due to its straight-forward natural defense mechanism [163-165]. MDMV resistance generated by RNA interference depends on the length of inverted-repeat sequence, the copy number of T-DNA integration and the repeatability of integration sites [166]. A longer hpRNA is more successful in the virus gene silencing rather than a shorter one $[167,168]$. Previously, the transfer of 150bp inverted-repeat sequence homologous to MDMV P1 enhanced maize virus resistance yet resulted in T2 lines with intermediate resistance or lower compared to the resistant control. Then, MDMV resistance was further improved through development of an hpRNA expression vector consisting of 451bp inverted-repeat sequences of MDMV protease gene (P1) [169]. Generally, genetic improvement of maize is considered to be a more efficient and more environmentally sustainable measure for virus management $[87,170]$.

\section{Concluding Remarks}

Detailed studies conducted on the genome and symptomatology of MDMV have resulted in successful visual, serological, as well as molecular, tests of diagnosis. This contributes to efforts of controlling MDM disease in order to reduce the yield loss caused in corn crops. The methods that were utilized in circumventing this problem include eradication of johnsongrass, SMM pre-treatment, resistance breeding and genetic engineering. The efficiency of currently available measures for curbing the spread of MDM disease has been proved, shown by the now rare infection of MDMV being observed in field corn. However, further initiatives can be focused on understanding of maize resistant genes using omics technology approach against MDMV for a better management of MDM disease of maize worldwide.

Author Contributions: Writing-Original Draft Preparation, M.K.; Writing-Review \& Editing, M.K., H.B. and I.I. Visualization, M.K. and H.B.; Project Administration, H.B. and I.I.; Funding Acquisition, H.B. and I.I.

Funding: This research was funded by Universiti Kebangsaan Malaysia grant numbers GGPM-2017-072 and DPP-2018-010. The APC was funded by Universiti Kebangsaan Malaysia.

Acknowledgments: The authors would like to thank Kathryn Ford from Bristol University for her editorial comments to improve the manuscript.

Conflicts of Interest: The authors declare no conflict of interest. 


\section{References}

1. Ludmerszki, E.; Rácz, I.; Rudnóy, S. S-methylmethionine alters gene expression of candidate genes in Maize dwarf mosaic virus infected and drought stressed maize plants. Acta Biol. Szeged. 2014, 58, 1-5.

2. Lukuyu, B.; Murdoch, A.; Mcleod, A.; Doward, P. The impact of Maize streak virus disease on quality and yield of maize forage outputs of the maize-dairy production systems in central highlands of Kenya. In Proceedings of the Livestock Development Group Student Conference, Focus on Livelihoods, University of Reading, Reading, UK, 16 October 2004; p. 16.

3. Redinbaugh, M.G.; Zambrano, J.L. Control of Virus Diseases in Maize. Adv. Virus Res. 2014, 90, $391-429$. [CrossRef] [PubMed]

4. Food and Agriculture Organizations. FAO Statistical Yearbook; Food and Agriculture Organization of the United Nations: Rome, Italy, 2013; ISBN 9788578110796.

5. Lapierre, H.; Signoret, P.A. Viruses and Virus Diseases of Poaceae (Gramineae); Institut National de la Recherche Agronomique: Paris, France, 2004; ISBN 2738010881.

6. Shukla, D.D.; Tosic, M.; Jilka, J.; Ford, R.E.; Toler, R.W.; Langham, M.A.C. Taxonomy of Potyviruses Infecting Maize, Sorghum, and Sugarcane in Australia and the United States as Determined by Reactivities of Polyclonal Antibodies Directed towards Virus-Specific N-Termini of Coat Proteins. Phytopathology 1989, 79, 223. [CrossRef]

7. Shukla, D.; Ward, C. Structure of Potyvirus Coat Proteins and Its Application in the Taxonomy of the Potyvirus Group. Adv. Virus Res. 1989, 36, 273-314. [CrossRef] [PubMed]

8. Seifers, D.L.; Salomon, R.; Marie-Jeanne, V.; Alliot, B.; Signoret, P.; Haber, S.; Loboda, A.; Ens, W.; She, Y.M.; Standing, K.G. Characterization of a novel potyvirus isolated from maize in Israel. Phytopathology 2000, 90, 505-513. [CrossRef] [PubMed]

9. Schurtleff, M.C. Compendium of Corn Diseases; APS Press: St. Paul, MN, USA, 1999; ISBN 0890540292.

10. Gell, G.; Balázs, E.; Petrik, K. Genetic diversity of Hungarian Maize dwarf mosaic virus isolates. Virus Genes 2010, 40, 277-281. [CrossRef] [PubMed]

11. Gordon, D.T.; Bradfute, O.E.; Gingery, R.E.; Knoke, J.K.; Louie, R.; Nault, L.R.; Scott, G.E. Introduction: History, geographical distribution, pathogen characteristics, and economic importance. In Viruses and Viruselike Disease of Maize in the United States; Ohio State University: Wooster, OH, USA, 1981; pp. 1-12.

12. Lübberstedt, T.; Ingvardsen, C.; Melchinger, A.E.; Xing, Y.; Salomon, R.; Redinbaugh, M.G. Two chromosome segments confer multiple potyvirus resistance in maize. Plant Breed. 2006, 125, 352-356. [CrossRef]

13. Lesemann, D.E.; Shukla, D.D.; Tosic, M.; Huth, W. Differentiation of the four viruses of the Sugarcane mosaic virus subgroup based on cytopathology. Potyvirus Taxon. 1992, 5, 353-361. [CrossRef]

14. Zielińska, L.; Trzmiel, K.; Jezewska, M. Ultrastructural changes in maize leaf cells infected with Maize dwarf mosaic virus and Sugarcane mosaic virus. Acta Biol. Crac. Ser. Bot. 2012, 54, 97-104. [CrossRef]

15. Matthews, R. The classification and nomenclature of viruses: Summary of results of meetings of the International Committee on Taxonomy of Viruses in Strasbourg. Intervirology 1982, 16, 53-60. [CrossRef]

16. Revers, F.; García, J.A. Molecular biology of potyviruses. Adv. Virus Res. 2015, 92, 101-199. [CrossRef] [PubMed]

17. Tosic, M.; Ford, R.E.; Shukla, D.D.; Jilka, J. Differentiation of Sugarcane, Maize dwarf, Johnsongrass, and Sorghum mosaic viruses based on reactions of oat and some sorghum cultivars. Plant Dis. 1990, 74, 549-552. [CrossRef]

18. Cao, P.; Eckstein, H.H.; De Rango, P.; Setacci, C.; Ricco, J.B.; de Donato, G.; Becker, F.; Robert-Ebadi, H.; Diehm, N.; Schmidli, J.; et al. Diagnostic Methods. Eur. J. Vasc. Endovasc. Surg. 2011, 42, S13-S32. [CrossRef]

19. Giolitti, F.; Herrera, M.G.; Madariaga, M.; Lenardon, S.L. Detection of Maize dwarf mosaic virus (MDMV) on maize in Chile. Maydica 2005, 50, 101-104.

20. Chauhan, R.A. Study of Filamentous Viruses in Maize and Smallgrains. Master's Thesis, University of Cape Town, Caoe Town, South Africa, 1985.

21. Gingery, R.E. Chemical and physical properties of maize viruses. South. Coop. Ser. Bull. 1981, 247, 38-39.

22. Shi, C.L.; Hsu, S.H. Maize dwarf mosaic virus of corn and sorghum in Beijing. Acta Phytopathol. Sin. 1979, 9, 35-40.

23. Mikel, M.A.; D'Arcy, C.J.; Rhodes, A.M.; Ford, R.E. Yield response of sweet corn to Maize dwarf mosaic virus. Plant Dis. 1981, 65, 900-901. [CrossRef] 
24. Mikel, M.A.; D'Arcy, C.J.; Rhodes, A.M.; Ford, R.E. Yield loss in sweet corn correlated with time of inoculation with Maize dwarf mosaic virus. Plant Dis. 1981, 65, 902-904. [CrossRef]

25. Gates, D.W.; Gudauskas, R.T. Photosynthesis, respiration and evidence of a metabolic inhibitor in corn infected with Maize dwarf mosaic virus. Phytopathology 1969, 59, 575-580.

26. Achon, M.A.; Larrañaga, A.; Alonso-Dueñas, N. The population genetics of Maize dwarf mosaic virus in Spain. Arch. Virol. 2012, 157, 2377-2382. [CrossRef] [PubMed]

27. Kong, P.; Steinbiss, H.H. Complete nucleotide sequence and analysis of the putative poliprotein of Maize dwarf mosaic virus genomic RNA (Bulgarian isolate). Arch. Virol. 1998, 143, 1791-1799. [CrossRef] [PubMed]

28. Urcuqui-Inchima, S.; Haenni, A.L.; Bernardi, F. Potyvirus proteins: A wealth of functions. Virus Res. 2001, 74, 1-2. [CrossRef]

29. Tuo, D.; Shen, W.; Yan, P.; Li, X.; Zhou, P. Rapid Construction of Stable Infectious Full-Length cDNA Clone of Papaya leaf distortion mosaic virus Using In-Fusion Cloning. Viruses 2015, 7, 6241-6250. [CrossRef] [PubMed]

30. Marie-Jeanne, V.; Ioos, R.; Peyre, J.; Alliot, B.; Signoret, P. Differentiation of Poaceae potyviruses by reverse transcription-polymerase chain reaction and restriction analysis. J. Phytopathol. 2000, 148, 141-151. [CrossRef]

31. Shukla, D.D.; Strike, P.M.; Tracy, S.L.; Gough, K.H.; Ward, C.W. The N and C termini of the coat proteins of potyviruses are surface-located and the $\mathrm{N}$ terminus contains the major virus-specific epitopes. J. Gen. Virol. 1988, 69, 1497-1508. [CrossRef]

32. Hill, J.H.; Ford, R.E.; Benner, H.I. Purification and partial characterization of Maize dwarf mosaic virus strain B (Sugarcane mosaic virus). J. Gen. Virol. 1973, 20, 327-339. [CrossRef]

33. Petrik, K.; Sebestyén, E.; Gell, G.; Balázs, E. Natural insertions within the N-terminal region of the coat protein of Maize dwarf mosaic potyvirus (MDMV) have an effect on the RNA stability. Virus Genes 2010, 40, 135-139. [CrossRef] [PubMed]

34. Olspert, A.; Chung, B.Y.W.; Atkins, J.F.; Carr, J.P.; Firth, A.E. Transcriptional slippage in the positive-sense RNA virus family Potyviridae. EMBO Rep. 2015, 16, 995-1004. [CrossRef] [PubMed]

35. Chung, B.Y.W.; Miller, W.A.; Atkins, J.F.; Firth, A.E. An overlapping essential gene in the Potyviridae. Proc. Natl. Acad. Sci. USA 2008, 105, 5897-5902. [CrossRef] [PubMed]

36. Hillung, J.; Elena, S.F.; Cuevas, J.M. Intra-specific variability and biological relevance of $P 3 N-P I P O$ protein length in potyviruses. BMC Evol. Biol. 2013, 13, 249. [CrossRef] [PubMed]

37. Vijayapalani, P.; Maeshima, M.; Nagasaki-Takekuchi, N.; Miller, W.A. Interaction of the trans-frame potyvirus protein P3N-PIPO with host protein PCaP1 facilitates potyvirus movement. PLoS Pathog. 2012, 8, e1002639. [CrossRef] [PubMed]

38. Masumi, M.; Mostafavi Neishabouri, F.; Nasrollahnejad, S.; Ghahramani, T.; Izadpanah, K. Determination of the Complete Sequence of the Genome of Maize dwarf mosaic virus; Plant Virology Research Center, College of Agriculture, Shiraz University: Shiraz, Iran, 2011.

39. Achon, M.A.; Serrano, L.; Alonso-Dueñas, N.; Porta, C. Complete genome sequences of Maize dwarf mosaic and Sugarcane mosaic virus isolates coinfecting maize in Spain. Arch. Virol. 2007, 152, 2073-2078. [CrossRef] [PubMed]

40. Stewart, L.R.; Bouchard, R.; Redinbaugh, M.G.; Meulia, T. Complete sequence and development of a full-length infectious clone of an Ohio isolate of Maize dwarf mosaic virus (MDMV). Virus Res. 2012, 165, 219-224. [CrossRef] [PubMed]

41. Maize Dwarf Mosaic Virus Isolate Italy, Complete Genome. Available online: https:/ /www.ncbi.nlm.nih. gov/nuccore/ 402216197 (accessed on 16 August 2018).

42. Boyer, J.C.; Haenni, A.L. Infectious Transcripts and cDNA Clones of RNA Viruses. Virology 1994, 198, 415-426. [CrossRef] [PubMed]

43. Duff-farrier, C.R.A.; Candresse, T.; Bailey, A.M.; Boonham, N.; Foster, G.D. Short Communication Evidence for different, host-dependent functioning of Rx against both wild-type and recombinant Pepino mosaic virus. Mol. Plant Pathol. 2016, 17, 120-126. [CrossRef] [PubMed]

44. Gell, G.M. Molecular Analysis of the Coat Protein Genes of Maize dwarf mosaic virus (MDMV) Populations. Ph.D. Thesis, University of Szent Istvan, Godollo, Hungary, 2011.

45. Ali, M.C.; Omar, A.S.; Natsuaki, T. An infectious full-length cDNA clone of Potato virus $Y^{N T N-N W}$, a recently reported strain of PVY that causes potato tuber necrotic ringspot disease. Arch. Virol. 2011, 156, 2039-2043. [CrossRef] 
46. Shepherd, R.J.; Holdeman, Q.L. Seed transmission of the Johnsongrass strain of the Sugarcane mosaic virus in Corn. Plant Dis. Report. 1965, 49, 468-469.

47. Snazelle, T.E.; Bancroft, J.B.; Ullstrup, A.J. Purification and serology of Maize dwarf mosaic and Sugarcane mosaic viruses. Phytopathology 1971, 61, 1059-1063. [CrossRef]

48. Langenberg, W.G. Leaf-dip serology for the determination of strain relationships of elongated plant viruses. Phytopathology 1974, 64, 128-131. [CrossRef]

49. Szirmai, J. The occurrence of stripe mosaic disease of maize in Hungary and possibilities of breeding for virus resistance. Acta Phytopathol. Hung. 1968, 3, 189-198.

50. Shukla, D.D.; Jilka, J.; Tosic, M.; Ford, R.E. A novel approach to the serology of potyviruses involving affinity-purified polyclonal antibodies directed towards virus-specific $\mathrm{N}$ termini of coat proteins. J. Gen. Virol. 1989, 70, 13-23. [CrossRef]

51. Seifers, D.L.; Hackerott, H.L. Estimates of yield loss and virus titre in sorghum hybrids infected with Maize dwarf mosaic virus strain B. Agric. Ecosyst. Environ. 1987, 19, 81-86. [CrossRef]

52. Hill, J.H.; Benner, H.I. Properties of potyvirus RNAs: Turnip mosaic, Tobacco etch, and Maize dwarf mosaic viruses. Virology 1976, 75, 419-432. [CrossRef]

53. Hill, J.H.; Shepherd, R.J. Biochemical properties of Turnip mosaic virus. Virology 1972, 47, 807-816. [CrossRef]

54. Moury, B.; Fabre, F.; Senoussi, R. Estimation of the number of virus particles transmitted by an insect vector. Proc. Natl. Acad. Sci. USA 2007, 104, 17891-17896. [CrossRef] [PubMed]

55. D'Arcy, C.J.; Nault, L.R. Insect transmission of plant viruses and mycoplasmalike and rickettsialike organisms. Plant Dis. 1982, 66, 99-104. [CrossRef]

56. Knoke, J.K.; Louie, R. Epiphytology of maize virus diseases. South. Coop. Ser. Bull. 1981, 247, 92-102.

57. Diagnostis Methods for Maize dwarf mosaic virus. Available online: http://www.padil.gov.au/pbt (accessed on 4 January 2018).

58. Bancroft, J.B.; Ullstrup, A.J.; Messieha, M.; Bracker, C.E.; Snazelle, T.E. Some biological and physical properties of a midwestern isolate of Maize dwarf mosaic virus. Phytopathology 1966, 56, 474-478.

59. Wang, R.Y.; Pirone, T.P. Potyvirus transmission is not increased by pre-acquisition fasting of aphids reared on artificial diet. J. Gen. Virol. 1996, 77, 3145-3148. [CrossRef] [PubMed]

60. Berger, P.; Toler, R.; Harris, K. Evidence for 2 modes of retention of Maize dwarf mosaic virus by Schizaphis graminum. Phytopatholog 1983, 73, 787.

61. Messieha, M. Studies on aphid transmission of Maize dwarf mosaic virus. Phytopathology 1967, 57, 956-959.

62. Thongmeearkom, P.; Ford, R.E.; Jedlinski, H. Aphid transmission of Maize dwarf mosaic virus strains. Phytopathology 1976, 66, 332-335. [CrossRef]

63. Salomon, R.; Bernardi, F. Inhibition of viral aphid transmission by the N-terminus of the Maize dwarf mosaic virus coat protein. Virology 1995, 213, 676-679. [CrossRef] [PubMed]

64. Pirone, T.P.; Blanc, S. Helper-dependent vector transmission of plant viruses. Annu. Rev. Phytopathol. 1996, 34, 227-247. [CrossRef] [PubMed]

65. Lacomme, C.; Glais, L.; Bellstedt, D.U.; Dupuis, B.; Karasev, A.V.; Jacquot, E. Virus Y: Biodiversity, Pathogenicity, Epidemiology and Management; Springer International Publishing: Cham, Switzerland, 2017; pp. 1-261.

66. Nault, L.R. Arthropod Transmission of plant viruses: A new synthesis. Ann. Entomol. Soc. Am. 1997, 90, 521-541. [CrossRef]

67. Atreya, C.D.; Raccah, B.; Pirone, T.P. A point mutation in the coat protein abolishes aphid transmissibility of a potyvirus. Virology 1990, 178, 161-165. [CrossRef]

68. Jiang, Y.X.; Lei, H.; Collar, J.L.; Martin, B.; Muniz, M.; Fereres, A. Probing and feeding behavior of two distinct biotypes of Bemisia tabaci (Homoptera: Aleyrodidae) on tomato plants. J. Econ. Entomol. 1999, 92, 357-366. [CrossRef]

69. Wang, R.Y.; Ammar, E.D.; Thornbury, D.W.; Lopez-Moya, J.J.; Pirone, T.P. Loss of potyvirus transmissibility and helper-component activity correlate with non-retention of virions in aphid stylets. J. Gen. Virol. 1996, 77, 861-867. [CrossRef] [PubMed]

70. Tu, J.C.; Ford, R.E. Factors affecting aphid transmission of Maize dwarf mosaic virus to corn. Phytopathology 1971, 61, 1516-1521. [CrossRef]

71. Watson, M.A.; Roberts, F.M. A comparative study of the transmission of Hyoscyamus virus 3, Potato virus $Y$ and Cucumber virus 1 by the vectors Myzus persicae (Sulz), M. circumflexus (Buckton), and Macrosiphum gei (Koch). Proc. R. Soc. Lond. B 1939, 127, 543-576. [CrossRef] 
72. Tsai, J.H.; Brown, L.G. Maize Dwarf Mosaic Virus; Plant Pathology Circular No. 320; Division of Plant Industry: Gainesville, FL, USA, 1989.

73. Teyssandier, E.E.; Nome, S.F.; Bo, E. Maize virus diseases in Argentina. In Proceedings of the International Maize Virus Disease Colloquium and Workshop, Wooster, OH, USA, 2-6 August 1982; The Ohio State University: Wooster, OH, USA, 1982; pp. 93-99.

74. Boothroyd, C.W. Seed transmission of Maize dwarf mosaic virus in sweet corn and yield reduction in plants from an infected seed lot. Am. Phytopathol. Soc. 1977, 4, 184. [CrossRef]

75. Hill, J.H.; Martinson, C.A.; Russell, W.A. Seed Transmission of Maize dwarf mosaic and Wheat streak mosaic viruses in Maize and Response of Inbred Lines. Crop Sci. 1974, 14, 232-235. [CrossRef]

76. Williams, L.E.; Findley, W.R.; Dollinger, E.J.; Ritter, R.M. Seed transmission studies of Maize dwarf mosaic virus in corn. Plant Dis. Report. 1968, 52, 863-864.

77. Mikel, M.A.; D'Arcy, C.J.; Ford, R.E. Seed Transmission of Maize dwarf mosaic virus in Sweet Corn. J. Phytopathol. 1984, 110, 185-191. [CrossRef]

78. Panayotou, P.C. Investigations on seed transmission of Maize dwarf mosaic virus and its effect on the establishment of seedlings. J. Plant Dis. Prot. 1981, 88, 621-625.

79. Nault, L.R.; Gordon, D.T.; Loayza, J.C. Maize virus and mycoplasma diseases in Peru. Trop. Pest Manag. 1981, 27, 363-369. [CrossRef]

80. Jones, M.W.; Boyd, E.C.; Redinbaugh, M.G. Responses of maize (Zea mays L.) near isogenic lines carrying Wsm1, Wsm2, and Wsm3 to three viruses in the potyviridae. Theor. Appl. Genet. 2011, 123, 729-740. [CrossRef] [PubMed]

81. Ford, R.E.; Tosic, M.; Shukla, D.D. Maize Dwarf Mosaic Virus: AAB Descriptions of Plant Viruses Online. 1989. Available online: http://sdb.im.ac.cn/vide/descr465.htm (accessed on 28 January 2018).

82. Krass, C.J.; Ford, R.E. Ultrastructure of Corn systemically infected with Maize dwarf mosaic virus. Phytopathology 1969, 59, 431-439.

83. Chen, S.; Das, P.; Hari, V. In situ localization of ATPase activity in cells of plants infected by Maize dwarf mosaic potyvirus. Arch. Virol. 1994, 134, 433-439. [CrossRef] [PubMed]

84. Gregory, L.V.; Ayers, J.E. Effect of inoculation with Maize dwarf mosaic virus at several growth stages on yield of sweet corn. Plant Dis. 1982, 66, 801-804. [CrossRef]

85. Mikel, M.A.; D'Arcy, C.J.; Rhodes, A.M.; Ford, R.E. Effect of Maize dwarf mosaic virus infection on sweet corn pollen and silk. Phytopathology 1982, 72, 428-431. [CrossRef]

86. Fuchs, E.; Grüntzig, M. Influence of Sugarcane mosaic virus (SCMV) and Maize dwarf mosaic virus (MDMV) on the growth and yield of two maize varieties. J. Plant Dis. Prot. 1995, 102, 44-50.

87. Williams, M.M.; Pataky, J.K. Interactions between maize dwarf mosaic and weed interference on sweet corn. Field Crop. Res. 2012, 128, 48-54. [CrossRef]

88. Antignus, Y. Comparative study of two Maize dwarf mosaic virus strains infecting corn and johnsongrass in Israel. Plant Dis. 1987, 71, 687-691. [CrossRef]

89. Tóbiás, I.; Palkovics, L. An unusual feature at the N-terminal end of the coat protein of Maize dwarf mosaic virus isolated in Hungary. J. Phytopathol. 2004, 152, 445-457. [CrossRef]

90. Robaglia, C.; Bruening, G.; Haseloff, J.; Gerlach, W.L. Evolution and replication of Tobacco ringspot virus satellite RNA mutants. EMBO J. 1993, 12, 2969-2976. [PubMed]

91. Jones, F.E.; Hill, J.H.; Durand, D.P. Detection and differentiation of Maize dwarf mosaic virus, strains A and B, by use of different class immunoglobulins in a double-antibody sandwich enzyme-linked immunosorbent assay. Phytopathology 1988, 78, 1118-1124. [CrossRef]

92. Sum, I.; Németh, M.; Pacsa, A.S. Detection of Maize dwarf mosaic virus with Enzyme-Linked Immunosorbent Assay (ELISA). J. Phytopathol. 1979, 95, 274-279. [CrossRef]

93. Lenardon, S.L.; Giolitti, F.J. Maize Dwarf Mosaic Potyvirus on Maize in Argentina; IFFIVE, INTA: Cordoba, Argentina, 2006.

94. Chen, J.; Chen, J.; Adams, M.J. A universal PCR primer to detect members of the Potyviridae and its use to examine the taxonomic status of several members of the family. Arch. Virol. 2001, 146, 757-766. [CrossRef] [PubMed]

95. Tang, Y.B.; Xing, D.; Zhu, D.B.; Zhou, X.M. High sensitive method detection of plant RNA viruses by Electrochemiluminescence reverse transcription PCR. Prog. Biomed. Opt. Imaging- Proc. SPIE 2007, 6534, 1-8. [CrossRef] 
96. Hill, E.K.; Hill, J.H.; Durand, D.P. Production of monoclonal antibodies to viruses in the potyvirus group: Use in radioimmunoassay. J. Gen. Virol. 1984, 65, 525-532. [CrossRef] [PubMed]

97. Krawczyk, K.; Uszczyńska-Ratajczak, B.; Majewska, A.; Borodynko-Filas, N. DNA microarray-based detection and identification of bacterial and viral pathogens of maize. J. Plant Dis. Prot. 2017, 124, 577-583. [CrossRef]

98. Van Slogteren, E.; Van Slogteren, D.H. Serological identification of plant viruses and serological diagnosis of virus diseases of plants. Annu. Rev. Microbiol. 1957, 11, 149-164. [CrossRef] [PubMed]

99. Siti-Rohana, B.O.; Ahmad, I.B.; Nasuruddin, B.A. Application of protein-A indirect ELISA (PAI-ELISA) for the detection of anti-Smith antibodies in systemic lupus erythematosus patients. World J. Microbiol. Biotechnol. 1995, 11, 206-208. [CrossRef] [PubMed]

100. Rybicki, E.P.; Von Wechmar, M.B. The serology of the Bromoviruses I. Serological interrelationships of the Bromoviruses. Virology 1981, 109, 391-402. [CrossRef]

101. Diaco, R.; Lister, R.M.; Hill, J.H.; Durand, D.P. Demonstration of serological relationships among isolates of barley yellow dwarf virus by using polyclonal and monoclonal antibodies. J. Gen. Virol. 1986, 67, 353-362. [CrossRef]

102. Koenig, R. ELISA in the study of homologous and heterologous reactions of plant viruses. J. Gen. Virol. 1978, 40, 309-318. [CrossRef]

103. Van Regenmortel, M.H.V. Serology and immunochemistry of plant viruses. Immunol. Commun. 1982, 11, 509-525. [CrossRef]

104. Ferro, D.N.; Mackenzie, J.D.; Margolies, D.C. Effect of mineral oil and a systemic insecticide on field spread of aphid-borne maize dwarf mosaic virus in sweet corn. J. Econ. Entomol. 1980, 73, 730-735. [CrossRef]

105. Ismail, B.S.; Ingon, D.; Omar, O. Effects of metolachlor on activities of enzymes in a Malaysian soil. J. Environ. Sci. Health Part B 1996, 31, 1267-1278. [CrossRef]

106. Toler, R.W. Maize dwarf mosaic, the most important virus disease of sorghum. Plant Dis. 1985, 69, 1011-1015. [CrossRef]

107. Gordon, D.T.; Bradfute, O.E.; Gingery, R.E.; Knoke, J.K.; Nault, L.R.; Loden, H.D.; Wilkinson, D. Maize virus disease complexes in the United States: Real and potential disease problems. In 33rd Annual Corn and Sorghum Research Conference; American Seed Trade Association: Washington, DC, USA, 1978; pp. 102-133.

108. Knoke, J.K.; Louie, R.; Madden, L.V.; Gordon, D.T. Spread of Maize dwarf mosaic virus from johnsongrass to corn. Plant Dis. 1983, 67, 367-370. [CrossRef]

109. Yossen, V.; Nome, S.F.; Latorre, B.A.; Conci, L.R. Occurrence of Maize dwarf mosaic virus (MDMV) in Johnson grass (Sorghum halepense (L.) Pers.) in Chile. Cienc. Investig. Agrar. 1988, 15, 39-45.

110. Angeles Achon, M.; Sobrepere, M. Incidence of potyviruses in commercial maize fields and their seasonal cycles in Spain. Zeitschrift für Pflanzenkrankheiten und Pflanzenschutz 2001, 108, 399-406.

111. Stewart, L.R.; Teplier, R.; Todd, J.C.; Jones, M.W.; Cassone, B.J.; Wijeratne, S.; Wijeratne, A.; Redinbaugh, M.G. Viruses in Maize and Johnsongrass in Southern Ohio. Phytopathology 2014, 104, 1360-1369. [CrossRef] [PubMed]

112. Hruska, A.J.; Gladstone, S.M.; Obando, R. Epidemic roller coaster: Maize stunt disease in Nicaragua. Am. Entomol. 1996, 42, 248-252. [CrossRef]

113. Shepherd, D.N.; Martin, D.P.; Van der Walt, E.; Dent, K.; Varsani, A.; Rybicki, E.P. Maize streak virus: An old and complex 'emerging' pathogen. Mol. Plant Pathol. 2010, 11, 1-12. [CrossRef] [PubMed]

114. Kim, J.; Leustek, T. Repression of cystathionine $\gamma$-synthase in Arabidopsis thaliana produces partial methionine auxotrophy and developmental abnormalities. Plant Sci. 2000, 151, 9-18. [CrossRef]

115. Hacham, Y.; Avraham, T.; Amir, R. The N-terminal region of Arabidopsis cystathionine $\gamma$-synthase plays an important regulatory role in methionine metabolism. Plant Physiol. 2002, 128, 454-462. [CrossRef] [PubMed]

116. Ludmerszki, E.; Paldi, K.; Racz, I.; Szigeti, Z.; Rudnoy, S.Z. The promising role of exogenous s-methylmethionine in agriculture, in the case of maize cultivation. Appl. Ecol. Environ. Res. 2014, 12, 777-785. [CrossRef]

117. Ranocha, P.; McNeil, S.D.; Ziemak, M.J.; Li, C.; Tarczynski, M.C.; Hanson, A.D. The S-methylmethionine cycle in angiosperms: Ubiquity, antiquity and activity. Plant J. 2001, 25, 575-584. [CrossRef] [PubMed]

118. Ko, S.; Eliot, A.C.; Kirsch, J.F. S-methylmethionine is both a substrate and an inactivator of 1-aminocyclopropane-1-carboxylate synthase. Arch. Biochem. Biophys. 2004, 421, 85-90. [CrossRef] [PubMed] 
119. Ludmerszki, E.; Rudnóy, S.; Almási, A.; Szigeti, Z.; Rácz, I. The beneficial effects of S-methyl-methionine in maize in the case of Maize dwarf mosaic virus infection. Acta Biol. Szeged. 2011, 55, 109-112.

120. Kocsis, M.G.; Nolte, K.D.; Rhodes, D.; Shen, T.L.; Gage, D.A.; Hanson, A.D. Dimethylsulfoniopropionate Biosynthesis inSpartina alterniflora 1: Evidence That S-Methylmethionine and Dimethylsulfoniopropylamine Are Intermediates. Plant Physiol. 1998, 117, 273-281. [CrossRef] [PubMed]

121. Ludmerszki, E.; Almasi, A.; Racz, I.; Szigeti, Z.; Solti, Á.; Olah, C.; Rudnoy, S. S-methylmethionine contributes to enhanced defense against Maize dwarf mosaic virus infection in maize. Braz. J. Bot. 2015, 38, 771-782. [CrossRef]

122. Asada, K. Radical production and scavenging in the chloroplasts. Photosynth. Environ. 1996, 123-150. [CrossRef]

123. Kingston-Smith, A.H.; Foyer, C.H. Bundle sheath proteins are more sensitive to oxidative damage than those of the mesophyll in maize leaves exposed to paraquat or low temperatures. J. Exp. Bot. 2000, 51, 123-130. [CrossRef] [PubMed]

124. Fryer, M.J.; Andrews, J.R.; Oxborough, K.; Blowers, D.A.; Baker, N.R. Relationship between $\mathrm{CO}_{2}$ assimilation, photosynthetic electron transport, and active $\mathrm{O}_{2}$ metabolism in leaves of maize in the field during periods of low temperature. Plant Physiol. 1998, 116, 571-580. [CrossRef] [PubMed]

125. Ludmerszki, E.; Chounramany, S.; Oláh, C.; Kátay, G.; Rácz, I.; Almási, A.; Solti, Á.; Bélai, I.; Rudnóy, S. Protective role of S-methylmethionine-salicylate in maize plants infected with Maize dwarf mosaic virus. Eur. J. Plant Pathol. 2017, 149, 145-156. [CrossRef]

126. Mayhew, D.E.; Ford, R.E. Detection of ribonuclease-resistant RNA in chloroplasts of corn leaf tissue infected with Maize dwarf mosaic virus. Virology 1974, 57, 503-509. [CrossRef]

127. Wei, T.; Huang, T.S.; McNeil, J.; Laliberté, J.F.; Hong, J.; Nelson, R.S.; Wang, A. Sequential recruitment of the endoplasmic reticulum and chloroplasts for plant potyvirus replication. J. Virol. 2010, 84, 799-809. [CrossRef] [PubMed]

128. Beddard, G.S.; Porter, G. Concentration quenching in chlorophyll. Nature 1976, 260, 366-367. [CrossRef]

129. Scott, G.E.; Findley, W.R. Breeding for resistance to maize virus diseases: A challenge. Maize Virus Dis. Newsl. 1984, 1984, 12-14.

130. Martin, I.F.; McCarthy, T.E.; Persely, D.M.; Greber, R.S. Breeding sweet corn for resistance to Sugarcane mosaic virus_-Johnsongrass strain in Australia. Maize Virus Dis. Newsl. 1984, 1, 15-16.

131. Kovács, G.; Milinkó, I.; Gyulavári, O.; Farády, L. Resistance of F1, F2 and BC1generations to Maize dwarf mosaic virus in maize. Arch. Phytopathol. Plant Prot. 1990, 26, 363-368. [CrossRef]

132. Chahal, G.S.; Gosal, S.S. Principles and Procedures of Plant Breeding: Biotechnological and Conventional Approaches; CRC Press: Boca Raton, FL, USA, 2002; ISBN 084931321X.

133. Lei, J.D.; Agrios, G.N. Mechanisms of resistance in corn to Maize dwarf mosaic virus. Phytopathology 1986, 76, 1034-1040. [CrossRef]

134. Louie, R. Effects of genotype and inoculation protocols on resistance evaluation of maize to Maize dwarf mosaic virus strains. Phytopathology 1986, 76, 769-773. [CrossRef]

135. Findley, W.R.; Dollinger, E.J.; Louie, R.; Knoke, J.K. Locating Genes for Maize Dwarf Mosaic Resistance by Means of Chromosomal Translocations in Corn (Zea mays L.) 1. Crop Sci. 1973, 13, 608-611. [CrossRef]

136. Scott, G.E.; Rosenkranz, E. Effectiveness of resistance to Maize dwarf mosaic and Maize chlorotic dwarf viruses in maize. Phytopathology 1981, 71, 937-941. [CrossRef]

137. Scott, G.E. Linkage between Maize dwarf mosaic virus resistance and endosperm color in maize. Crop Sci. 1989, 29, 1478-1480. [CrossRef]

138. McMullen, M.D.; Louie, R. Identification of a gene for resistance to Wheat streak mosaic virus in maize. Phytopathology 1991, 81, 624-627. [CrossRef]

139. Ng, C.H.; Wickneswari, R.; Salmijah, S.; Teng, Y.T.; Ismail, B.S. Gene polymorphisms in glyphosate-resistant and -susceptible biotypes of Eleusine indica from Malaysia. Weed Res. 2003, 43, 108-115. [CrossRef]

140. McMullen, M.D.; Louie, R. The linkage of molecular markers to a gene controlling the symptom response in maize to Maize dwarf mosaic virus. Mol. Plant-Microbe Interact. 1989, 2, 309-311. [CrossRef]

141. Jones, M.W.; Redinbaugh, M.G.; Louie, R. The Mdm1 locus and maize resistance to Maize dwarf mosaic virus. Plant Dis. 2007, 91, 185-190. [CrossRef]

142. Louie, R.; Findley, W.R.; Knoke, J.K.; McMullen, M.D. Genetics basis of resistance in maize to five Maize dwarf mosaic virus strains. Crop Sci. 1991, 31, 14-18. [CrossRef] 
143. Zambrano, J.L.; Jones, M.W.; Brenner, E.; Francis, D.M.; Tomas, A.; Redinbaugh, M.G. Genetic analysis of resistance to six virus diseases in a multiple virus-resistant maize inbred line. Theor. Appl. Genet. 2014, 127, 867-880. [CrossRef] [PubMed]

144. Pataky, J.K.; Murphy, J.F.; D'arcy, C.J. Resistance to Maize dwarf mosaic virus, severity of symptoms, titer of virus, and yield of sweet corn. Plant Dis. 1990, 74, 359-364. [CrossRef]

145. Scott, G.E.; Rosenkranz, E. Variable Reaction within Corn Inbreds to Maize dwarf mosaic virus not Genetically Controlled1. Crop Sci. 1987, 27, 78-79. [CrossRef]

146. Jones, R.K.; Tolin, S.A. Concentration of Maize dwarf mosaic virus in susceptible and resistant corn hybrids. Phytopathology 1972, 62, 640-644. [CrossRef]

147. Kuntze, L.; Fuchs, E.; Grüntzig, M.; Schulz, B.; Klein, D.; Melchinger, A.E. Resistance of early-maturing European maize germplasm to Sugarcane mosaic virus (SCMV) and Maize dwarf mosaic virus (MDMV). Plant Breed. 1997, 116, 499-501. [CrossRef]

148. Law, M.D.; Moyer, J.W.; Payne, G.A. The effect of host resistance on pathogenesis of Maize dwarf mosaic virus. Phytopathology 1989, 79, 757-761. [CrossRef]

149. Azad, M.; Kalam, A.; Amin, L.; Sidik, N.M. Gene technology for Papaya ringspot virus disease management. Sci. World J. 2014, 2014, 768038. [CrossRef] [PubMed]

150. Prins, M.; Laimer, M.; Noris, E.; Schubert, J.; Wassenegger, M.; Tepfer, M. Strategies for antiviral resistance in transgenic plants. Mol. Plant Pathol. 2008, 9, 73-83. [CrossRef] [PubMed]

151. Louie, R. Vascular puncture of maize kernels for the mechanical transmission of Maize white line mosaic virus and other viruses of maize. Phytopathology 1995, 85, 139-143. [CrossRef]

152. Atabekov, J.G.; Dorokhov, Y.L. Plant virus-specific transport function and resistance of plants to viruses. Adv. Virus Res. 1984, 29, 313-364. [CrossRef] [PubMed]

153. Bennetzen, J.L.; Hake, S.C. Handbook of Maize: Its Biology; Springer: New York, NY, USA, 2009; pp. 121-126. ISBN 978-0-387-79417-4e.

154. Cassone, B.J.; Chen, Z.; Chiera, J.; Stewart, L.R.; Redinbaugh, M.G. Responses of highly resistant and susceptible maize to vascular puncture inoculation with Maize dwarf mosaic virus. Physiol. Mol. Plant Pathol. 2014, 86, 19-27. [CrossRef]

155. Xing, Y.; Ingvardsen, C.; Salomon, R.; Lübberstedt, T. Analysis of Sugarcane mosaic virus resistance in maize in an isogenic dihybrid crossing scheme and implications for breeding potyvirus-resistant maize hybrids. Genome 2006, 49, 1274-1282. [CrossRef] [PubMed]

156. Johal, G.S.; Briggs, S.P. Reductase activity encoded by the HM1 disease resistance gene in maize. Science 1992, 258, 985-987. [CrossRef] [PubMed]

157. Martin, G.B.; Brommonschenkel, S.H.; Chunwongse, J.; Frary, A.; Ganal, M.W.; Spivey, R.; Tanksley, S.D. Map-based cloning of a protein kinase gene conferring disease resistance in tomato. Science 1993, 262, 1432-1436. [CrossRef] [PubMed]

158. Simcox, K.D.; McMullen, M.D.; Louie, R. Co-segregation of the Maize dwarf mosaic virus resistance gene, $M d m 1$, with the nucleolus organizer region in maize. Theor. Appl. Genet. 1995, 90, 341-346. [CrossRef] [PubMed]

159. Xi, Z.Y.; Zhang, S.H.; Li, X.H.; Xie, C.X.; Li, M.S.; Hao, Z.F.; Zhang, D.G.; Liang, Y.H.; Bai, L.; Zhang, S.H. Identification and mapping of a novel Sugarcane mosaic virus resistance gene in maize. Acta Agron. Sin. 2008, 34, 1494-1499. [CrossRef]

160. Liu, X.; Tan, Z.; Li, W.; Zhang, H.; He, D. Cloning and transformation of SCMV CP gene and regeneration of transgenic maize plants showing resistance to SCMV strain MDB. Afr. J. Biotechnol. 2009, 8, 3747-3753.

161. Murry, L.E.; Elliott, L.G.; Capitant, S.A.; West, J.A.; Hanson, K.K.; Scarafia, L.; Johnston, S.; DeLuca-Flaherty, C.; Nichols, S.; Cunanan, D.; et al. Transgenic corn plants expressing MDMV strain B coat protein are resistant to mixed infections of Maize dwarf mosaic virus and Maize chlorotic mottle virus. Nat. Biotechnol. 1993, 11, 1559-1564. [CrossRef]

162. Zhang, Z.Y.; Fu, F.L.; Gou, L.; Wang, H.G.; Li, W.C. RNA interference-based transgenic maize resistant to Maize dwarf mosaic virus. J. Plant Biol. 2010, 53, 297-305. [CrossRef]

163. Behboodian, B.; Ali, Z.M.; Ismail, I.; Zainal, Z. Postharvest analysis of lowland transgenic tomato fruits harboring hpRNAi-ACO1 construct. Sci. World J. 2012, 2012, 439870. [CrossRef] [PubMed] 
164. Fahim, M.; Ayala-Navarrete, L.; Millar, A.A.; Larkin, P.J. Hairpin RNA derived from viral NIa gene confers immunity to Wheat streak mosaic virus infection in transgenic wheat plants. Plant Biotechnol. J. 2010, 8, 821-834. [CrossRef] [PubMed]

165. Praveen, S.; Ramesh, S.V.; Mishra, A.K.; Koundal, V.; Palukaitis, P. Silencing potential of viral derived RNAi constructs in Tomato leaf curl virus-AC4 gene suppression in tomato. Transgenic Res. 2010, 19, 45-55. [CrossRef] [PubMed]

166. Zhang, Z.Y.; Yang, L.; Zhou, S.F.; Wang, H.G.; Li, W.C.; Fu, F.L. Improvement of resistance to maize dwarf mosaic virus mediated by transgenic RNA interference. J. Biotechnol. 2011, 153, 181-187. [CrossRef] [PubMed]

167. Chen, Y.K.; Lohuis, D.; Goldbach, R.; Prins, M. High frequency induction of RNA-mediated resistance against Cucumber mosaic virus using inverted repeat constructs. Mol. Breed. 2004, 14, 215-226. [CrossRef]

168. Hily, J.M.; Ravelonandro, M.; Damsteegt, V.; Bassett, C.; Petri, C.; Liu, Z.; Scorza, R. Plum pox virus coat protein gene Intron-hairpin-RNA (ihpRNA) constructs provide resistance to Plum pox virus in Nicotiana benthamiana and Prunus domestica. J. Am. Soc. Hortic. Sci. 2007, 132, 850-858.

169. Zhang, Z.Y.; Wang, Y.G.; Shen, X.J.; Li, L.; Zhou, S.F.; Li, W.C.; Fu, F.L. RNA interference-mediated resistance to Maize dwarf mosaic virus. Plant Cell Tissue Organ Cult. 2013, 113, 571-578. [CrossRef]

170. Redinbaugh, M.G.; Jones, M.W.; Gingery, R.E. The genetics of virus resistance in maize (Zea mays L.). Maydica 2004, 49, 183-190.

(C) 2018 by the authors. Licensee MDPI, Basel, Switzerland. This article is an open access article distributed under the terms and conditions of the Creative Commons Attribution (CC BY) license (http:// creativecommons.org/licenses/by/4.0/). 